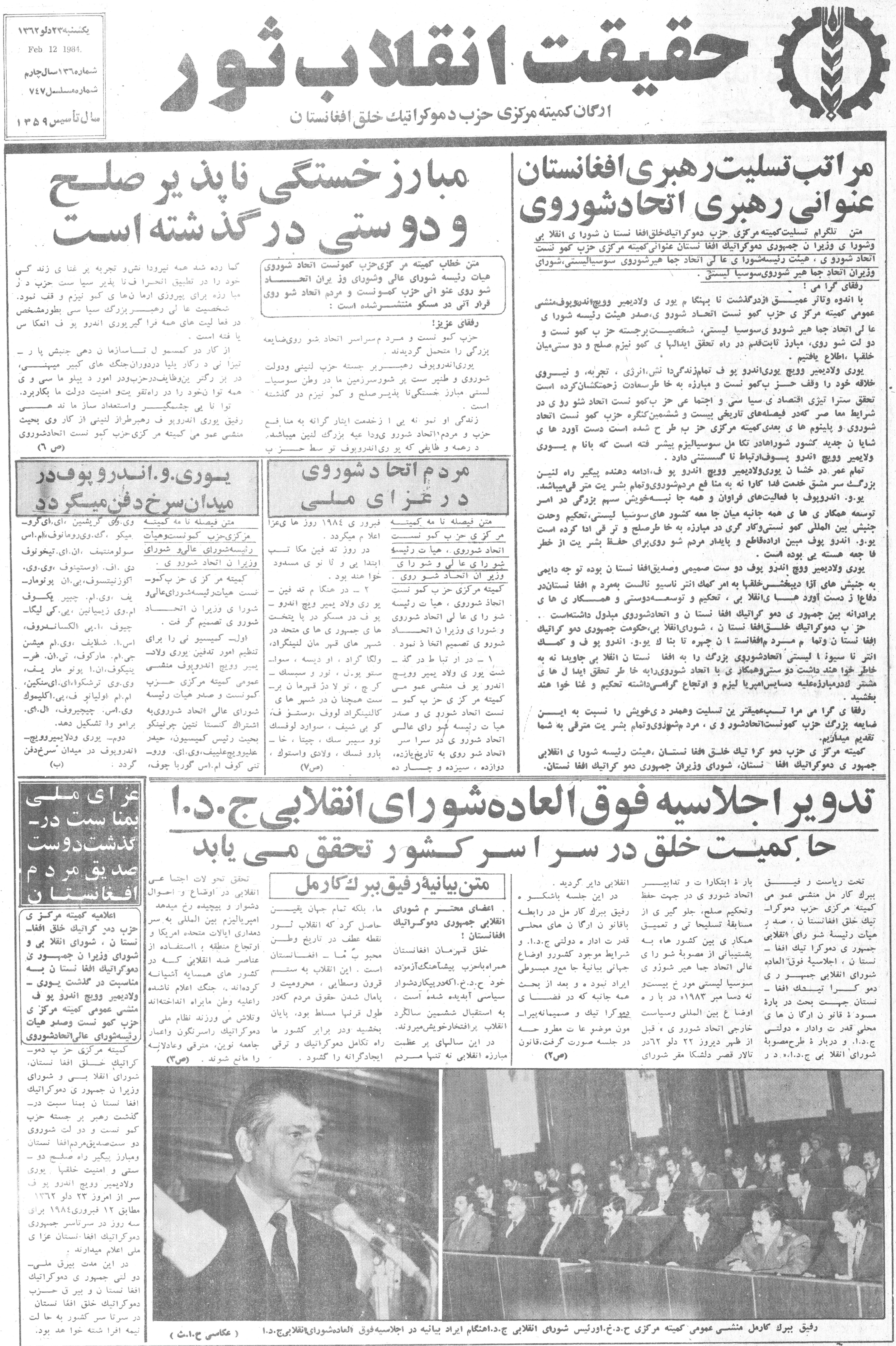


مقيلتسا أقلابثور

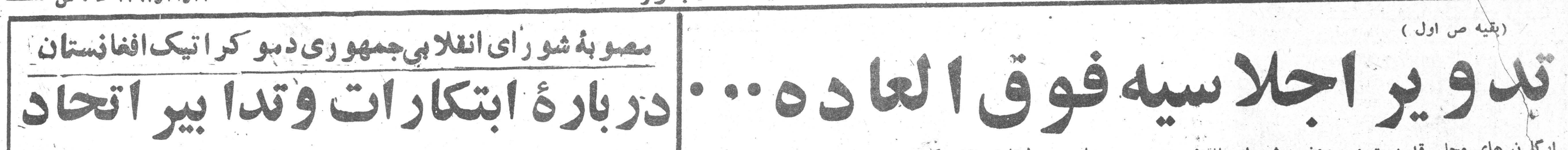

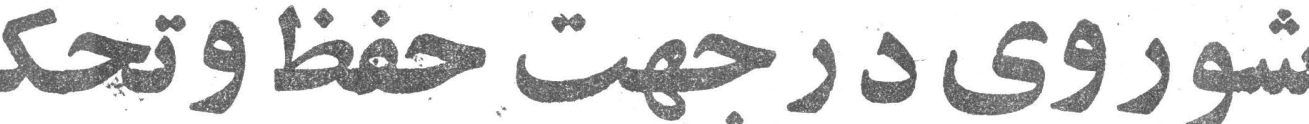

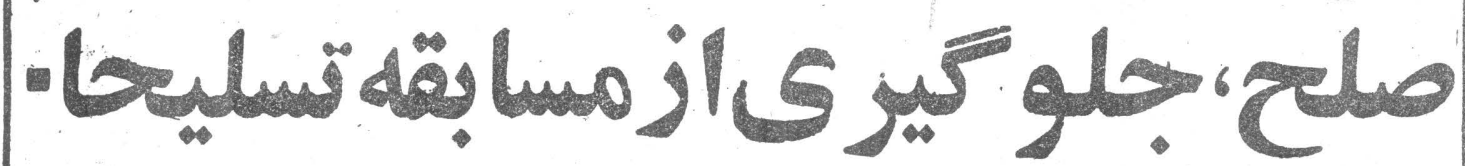

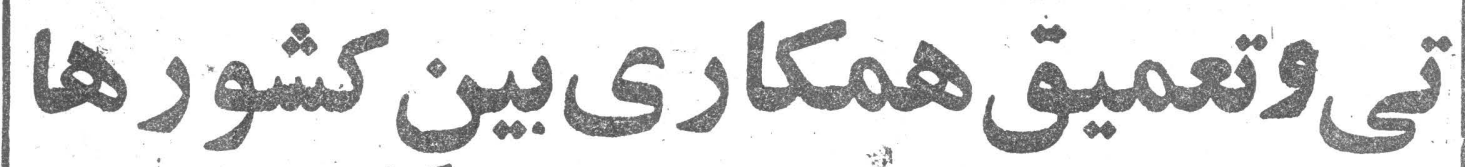

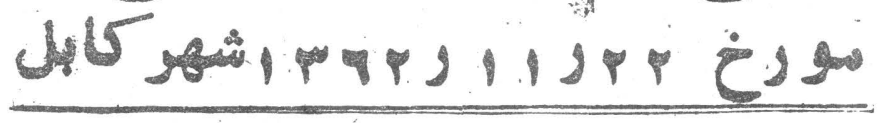

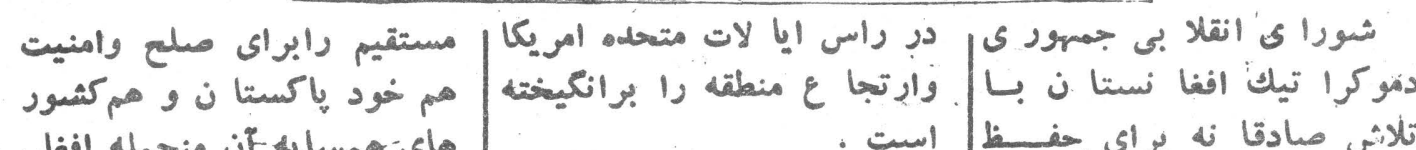

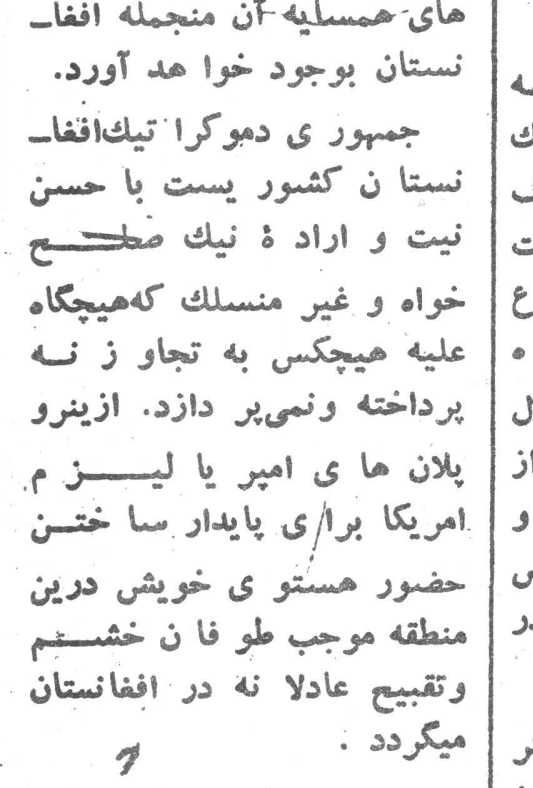

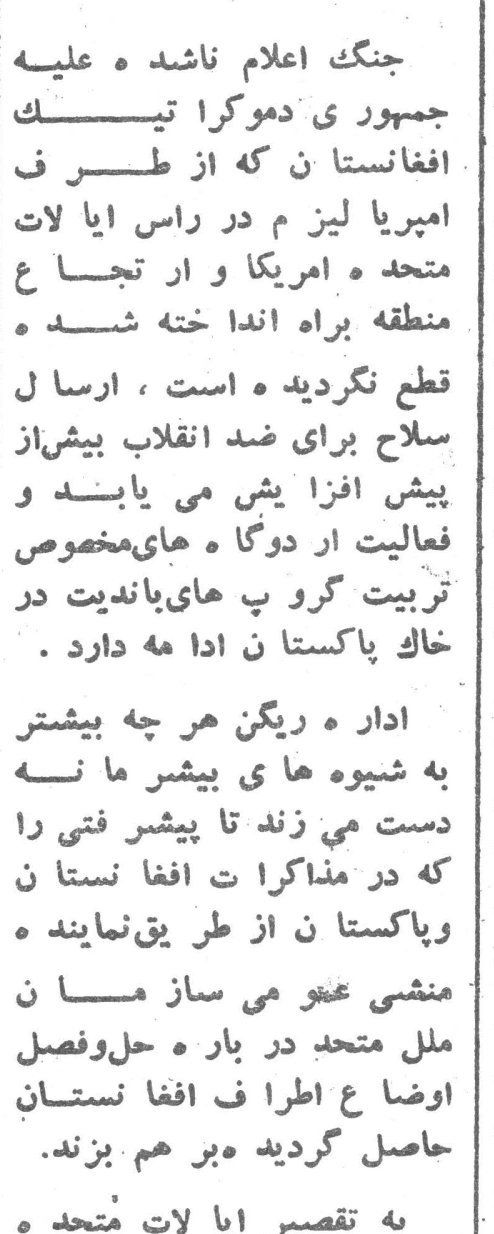

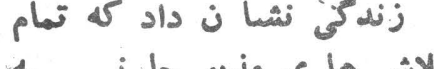

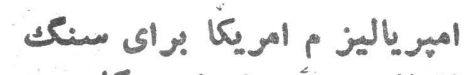

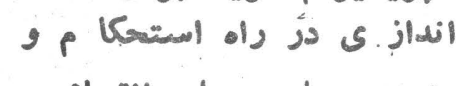

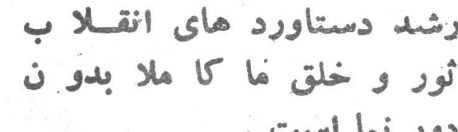

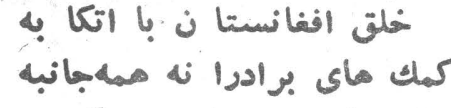

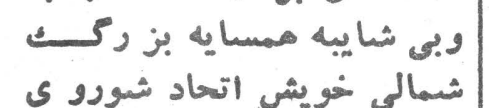

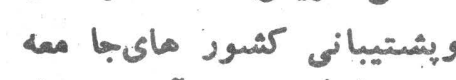

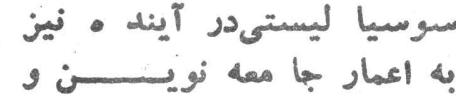

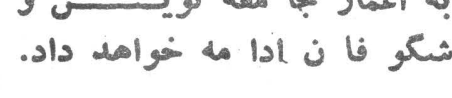

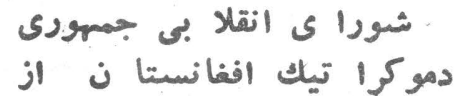

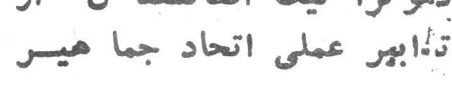

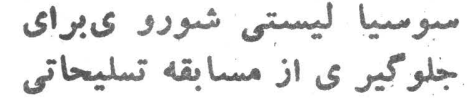

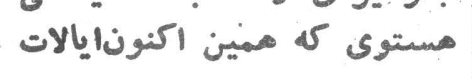

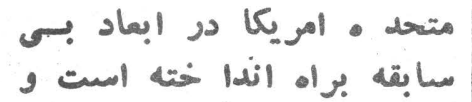

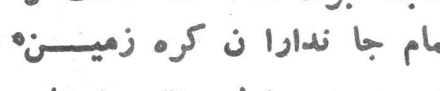
ئك

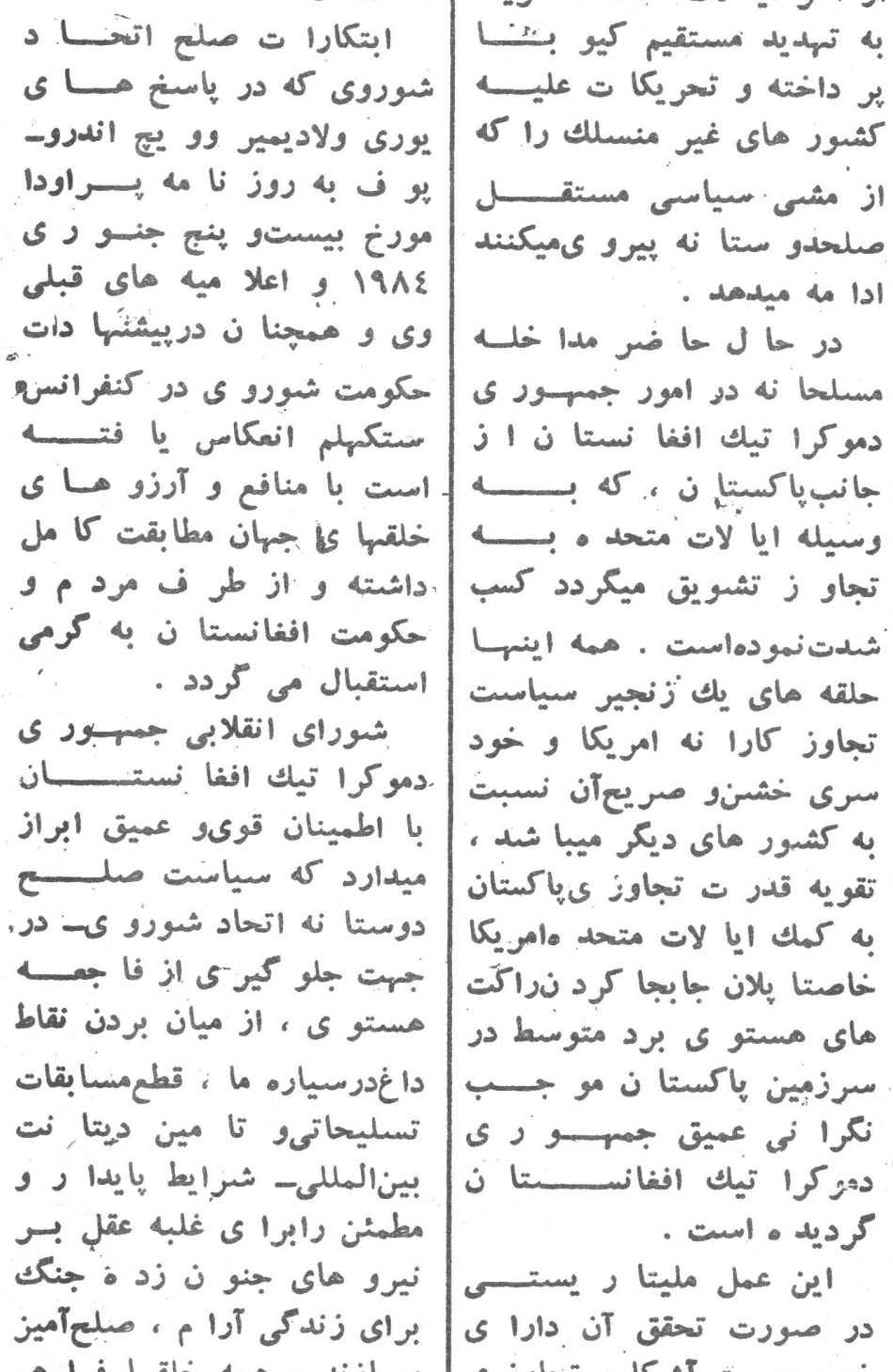

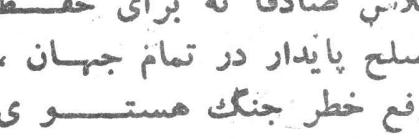

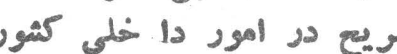

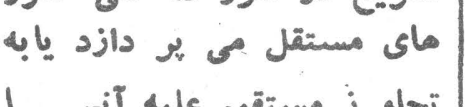

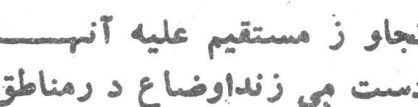

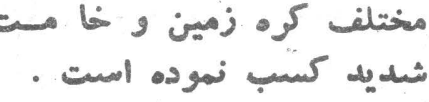

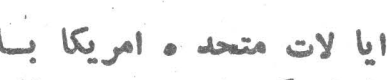

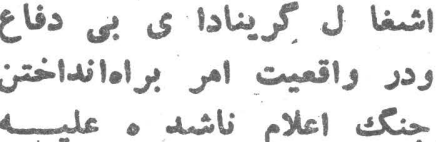

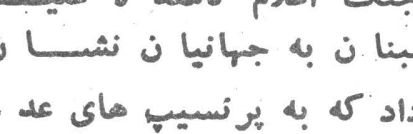

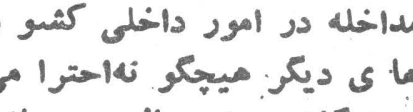

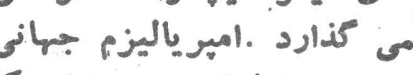

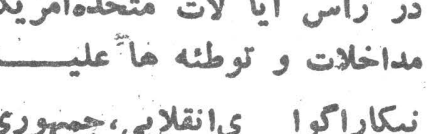

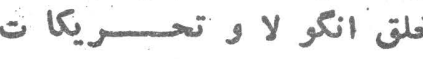

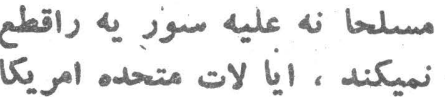

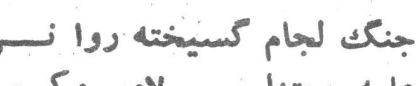

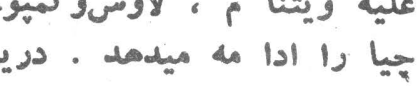

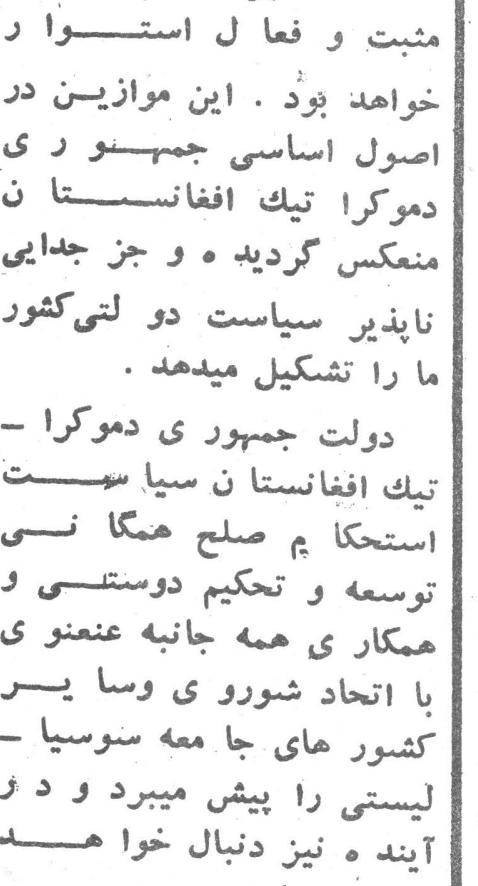

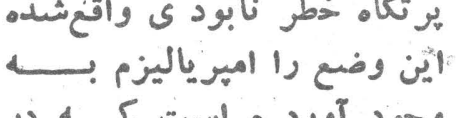
(1)

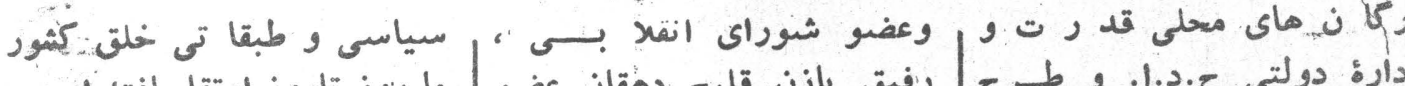

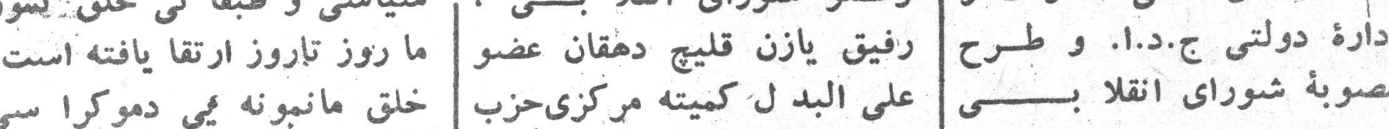

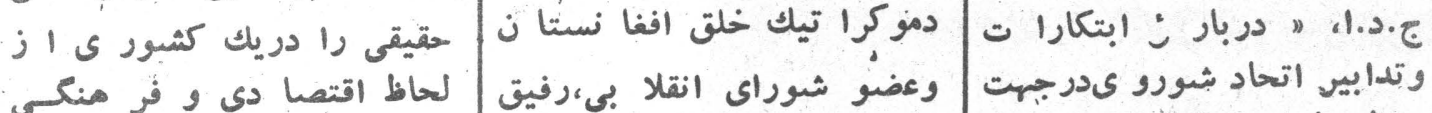
(t)

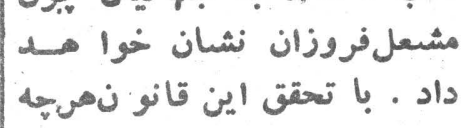

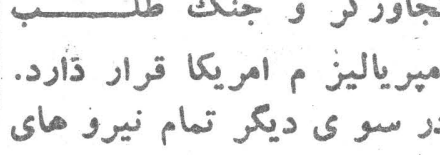

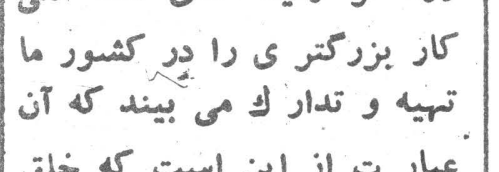

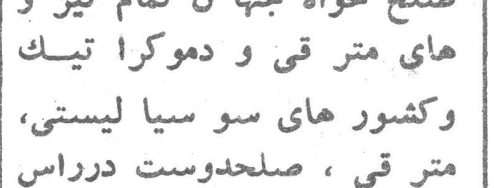

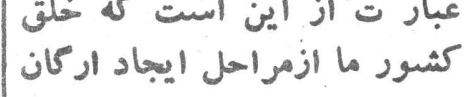

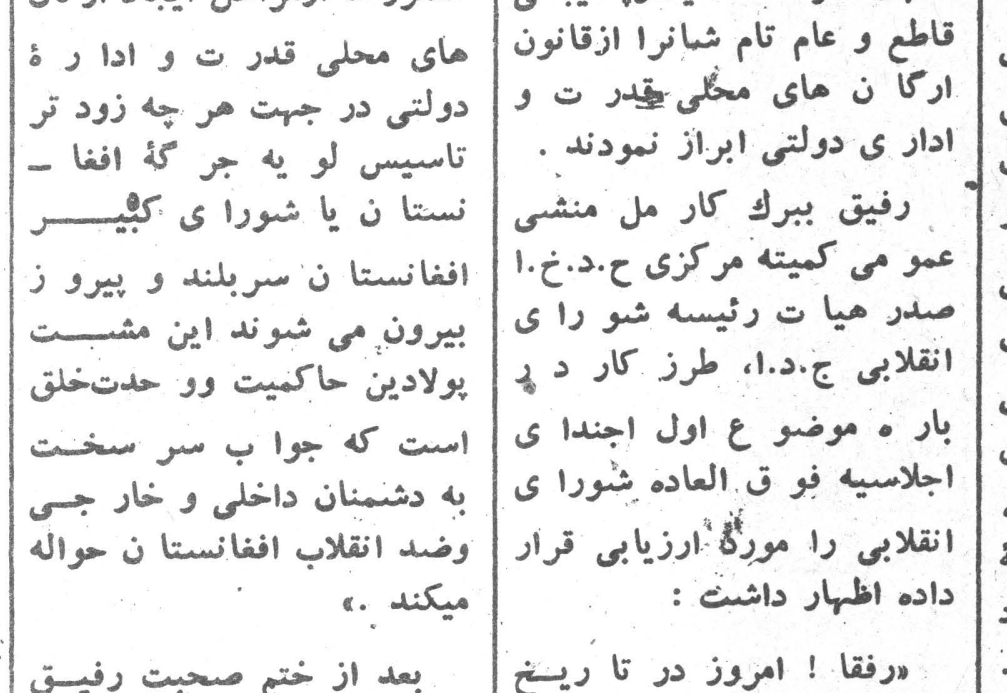

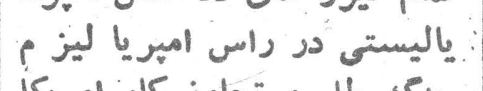

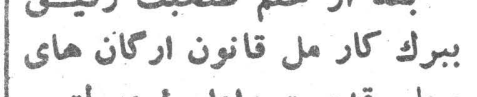
كثور ما دريكمز حله حسناسى

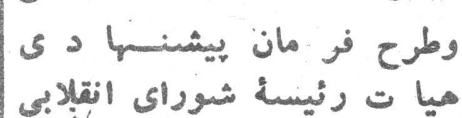

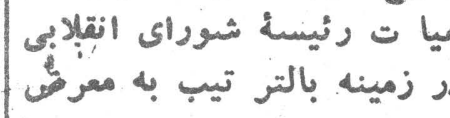

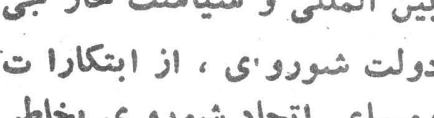

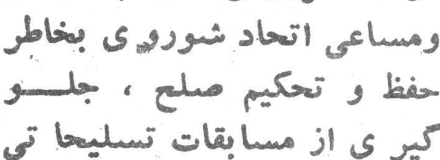

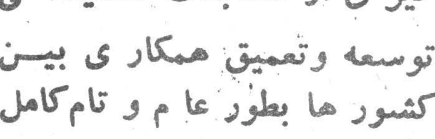

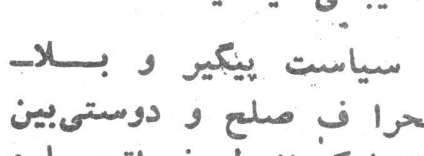

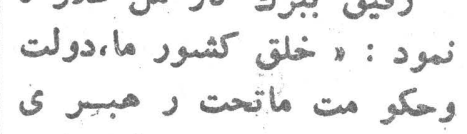

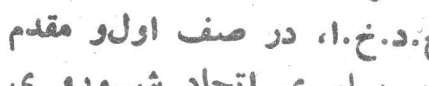

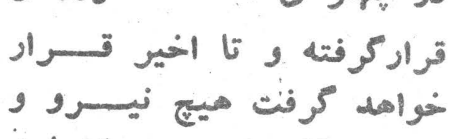

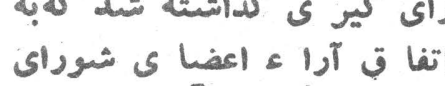

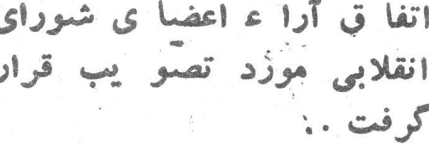

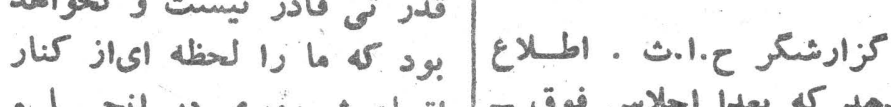

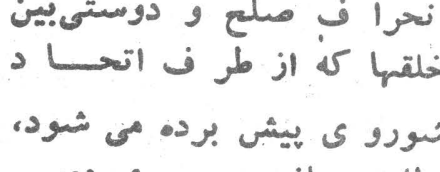

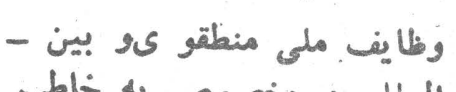

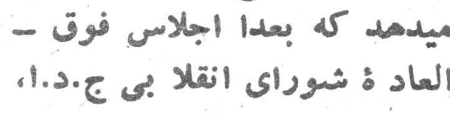

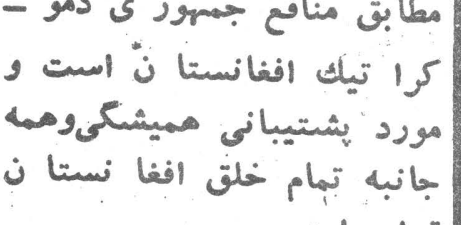

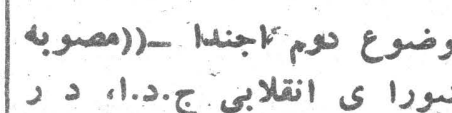
تان بك נת أ

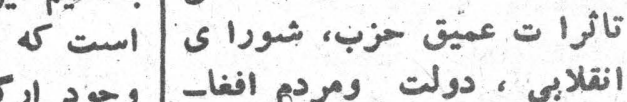

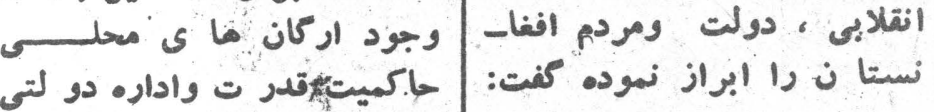

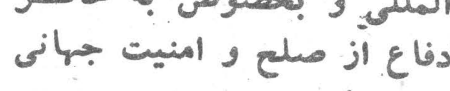

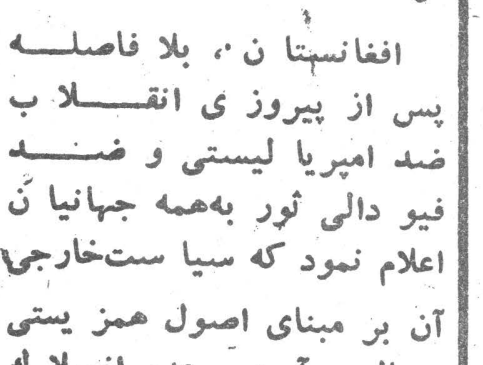

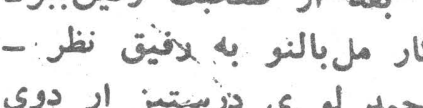

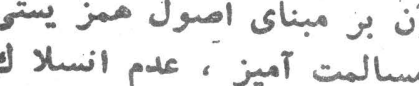

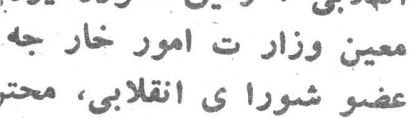

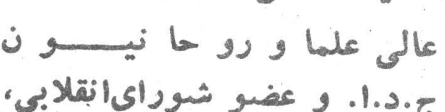

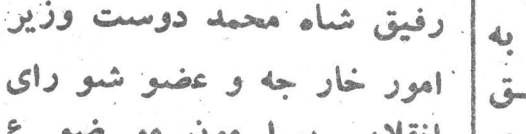

زمير ئس

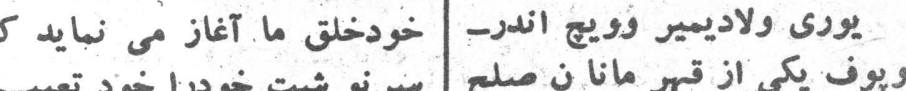

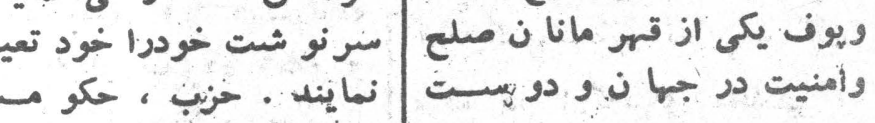

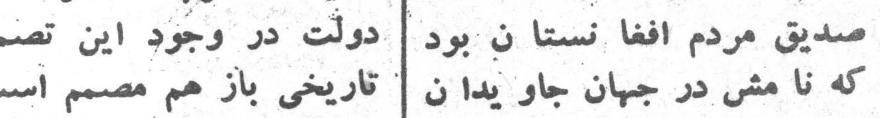

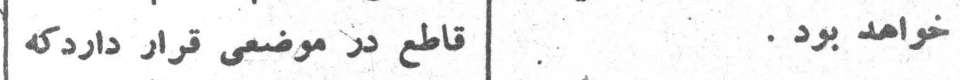

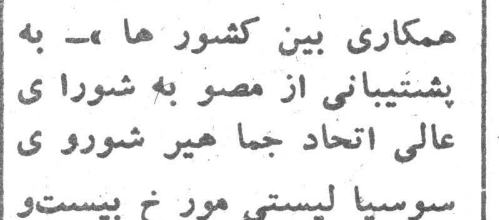

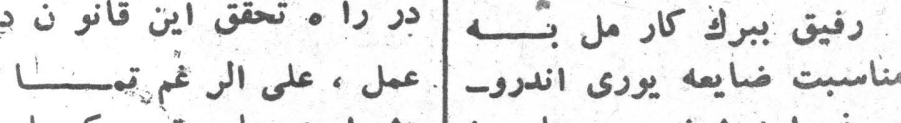

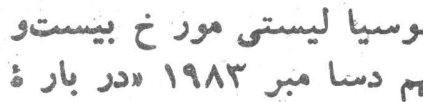

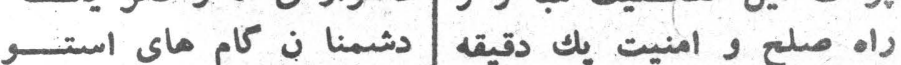

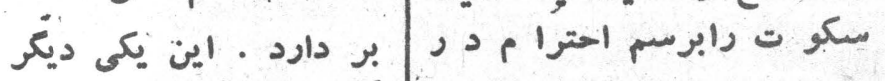

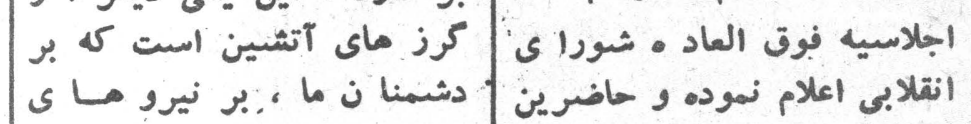

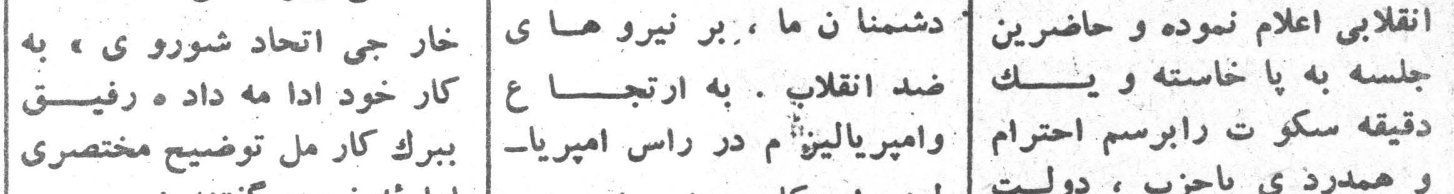
$\mid$

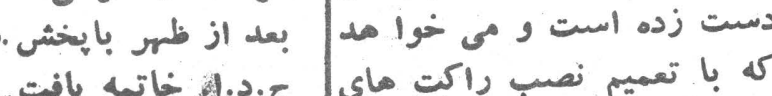

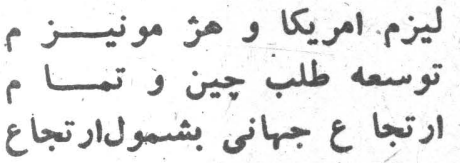

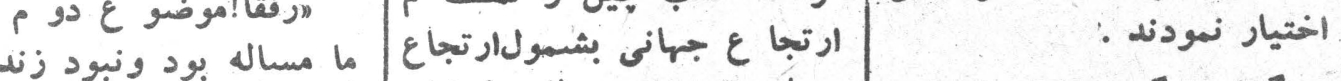

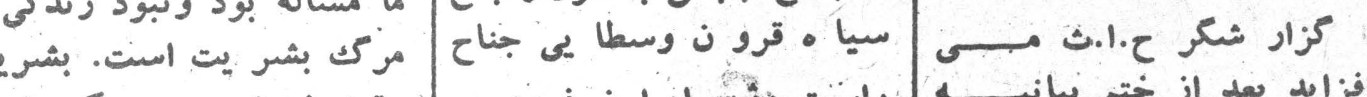

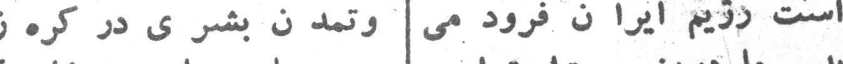

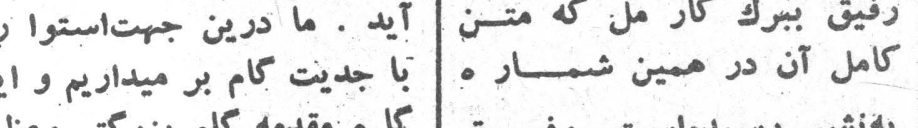

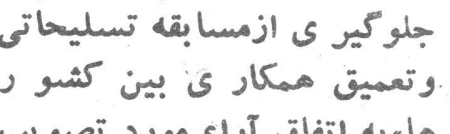
كار اجلاسيئ فوقِ العاد

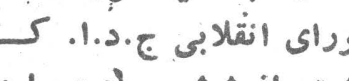

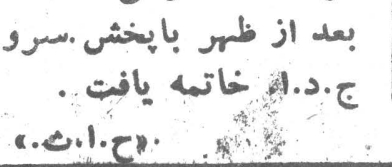

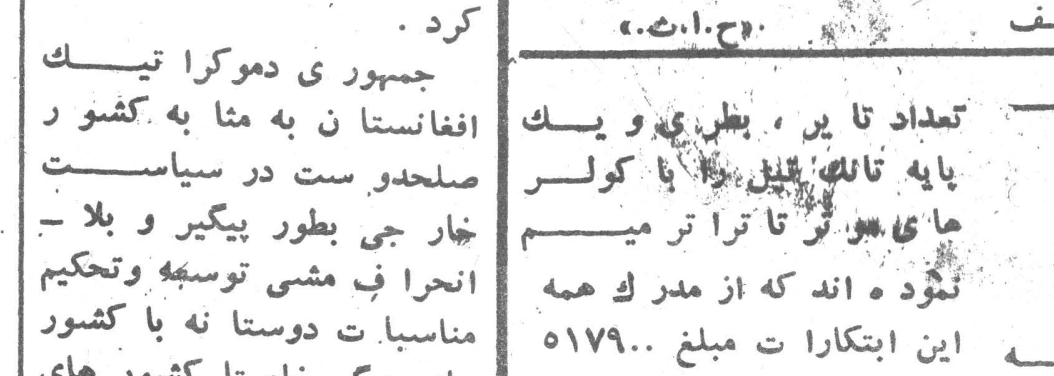

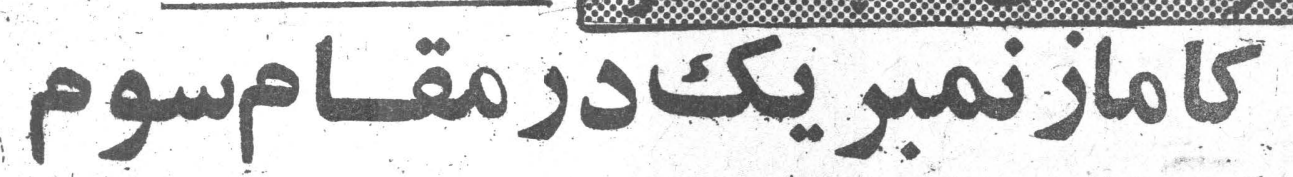

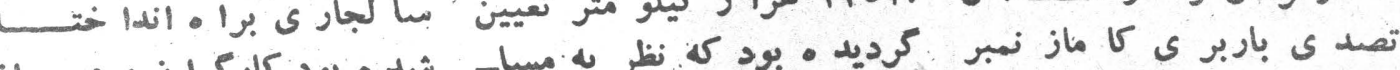

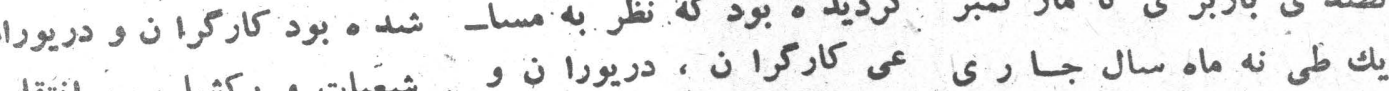

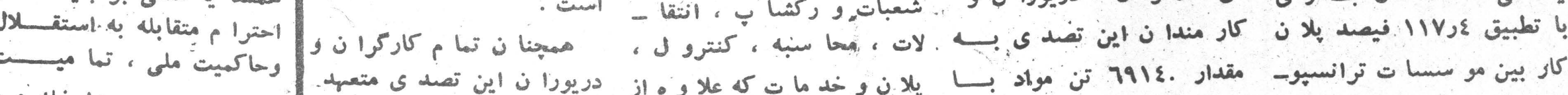

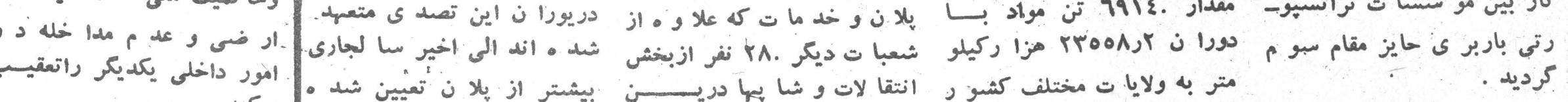

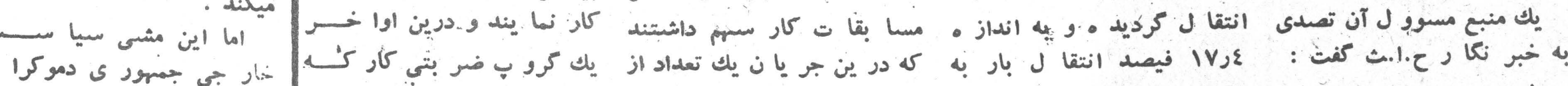

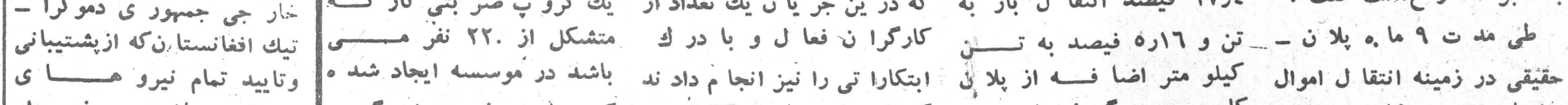




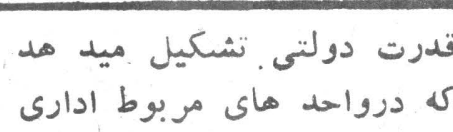

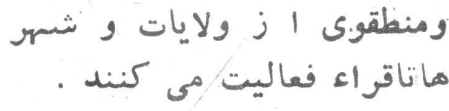

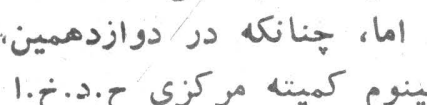

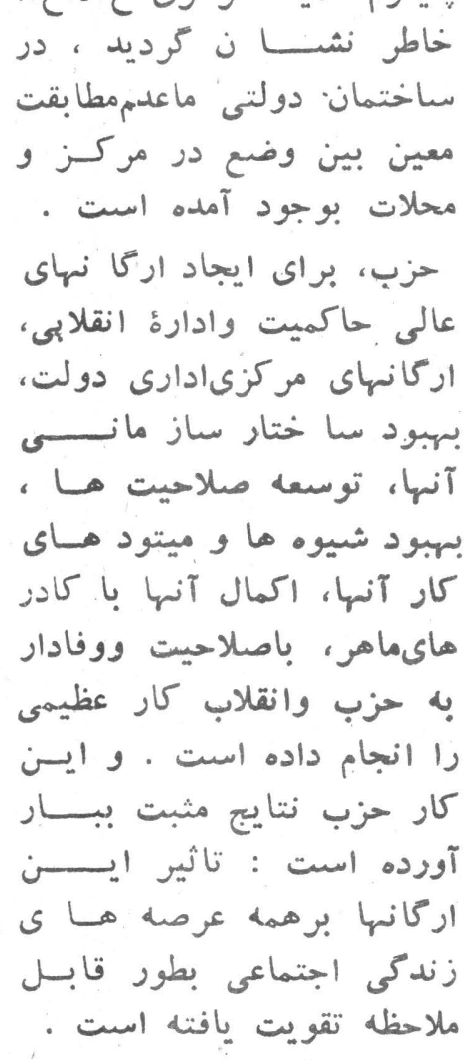

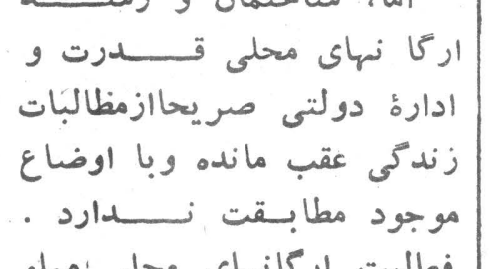

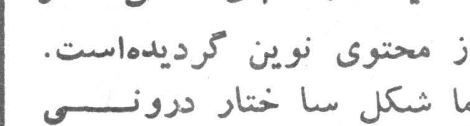

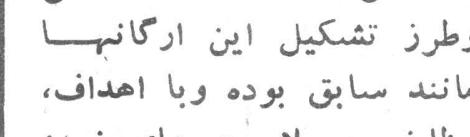

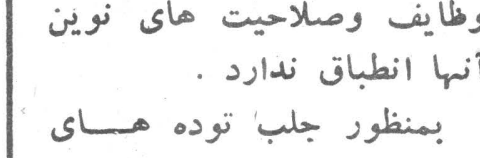

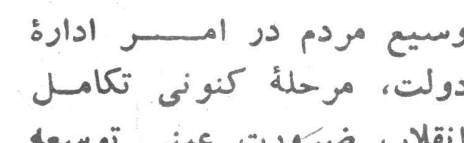

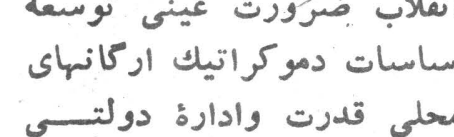

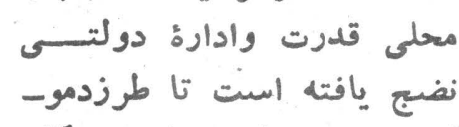

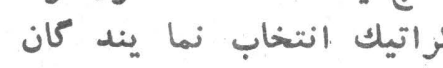

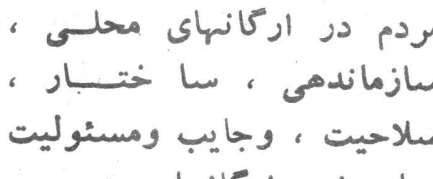

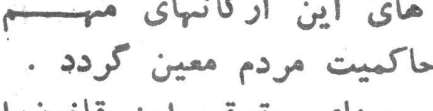

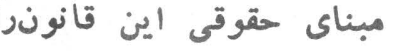

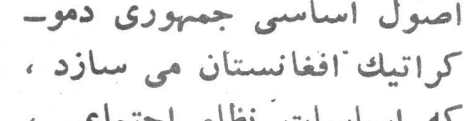

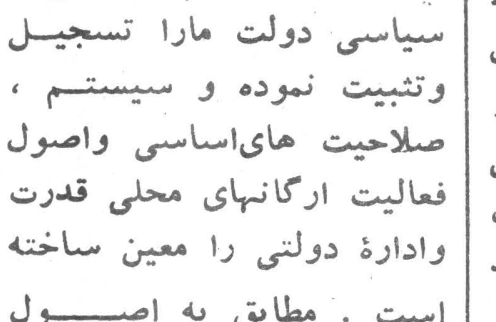

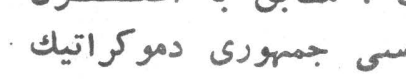

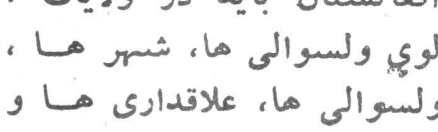

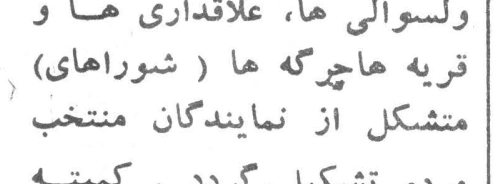

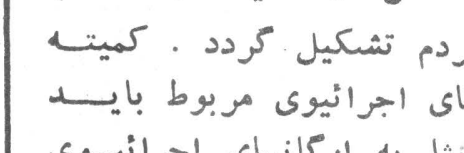

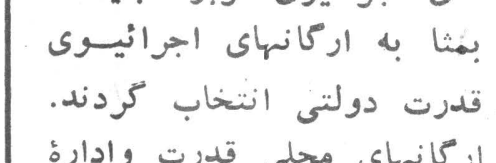

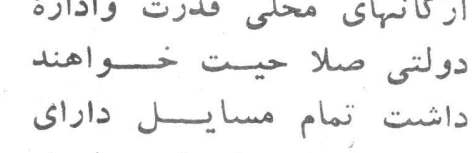

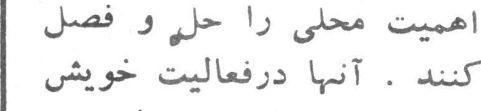

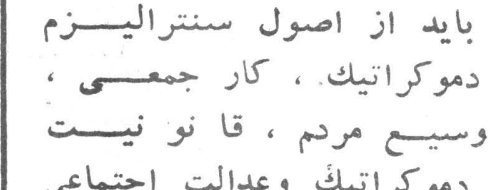

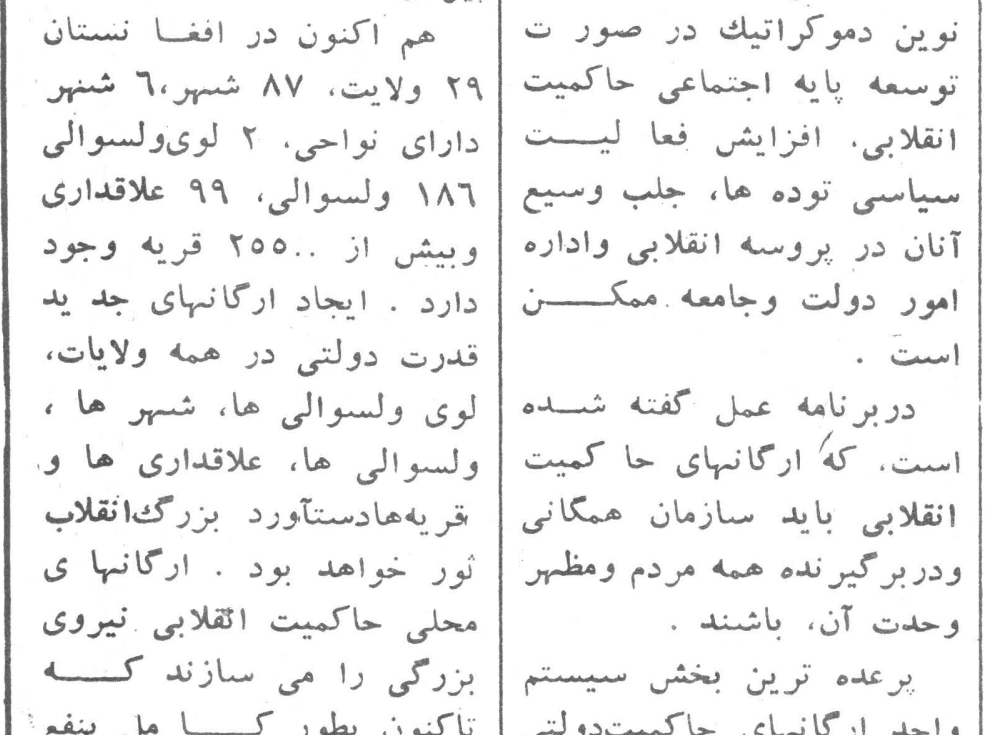

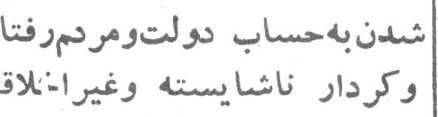

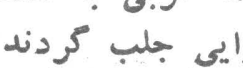

\section{متــنبيانيــهـرفيـقببر ككــارمل}

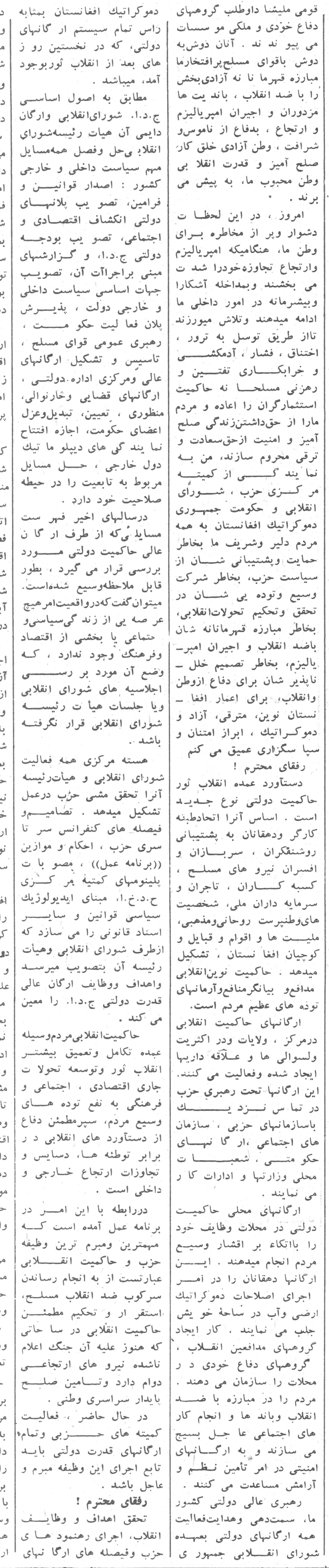

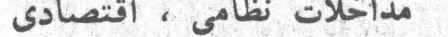

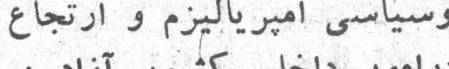

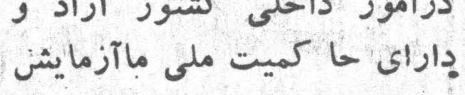

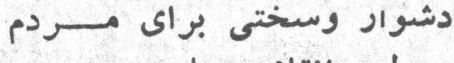

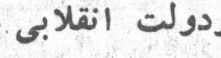

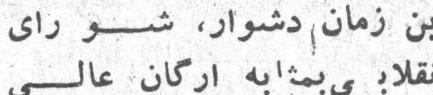
حاكميت دولتى توجه ومساعنى

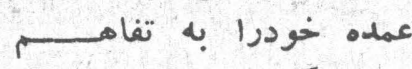
مبمبسكى نيرو هاى انقلابى

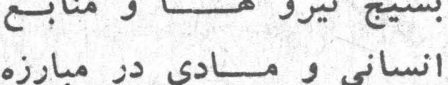

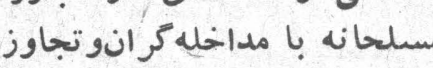
كران خارجى و ضل اند انقــلاب

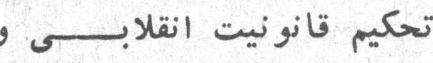
اوضساع دراد وعادى شدن بيت بيشتر

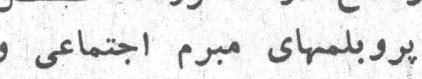

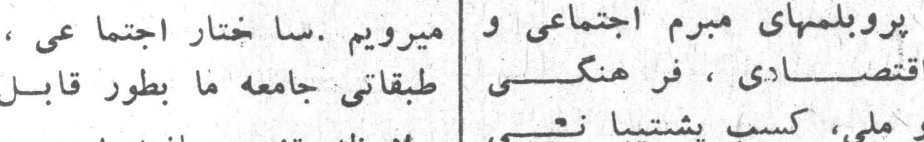

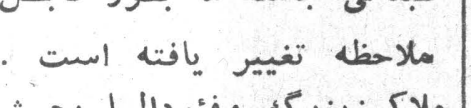

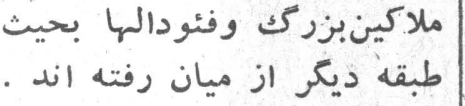

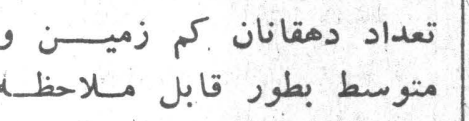

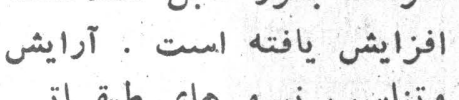

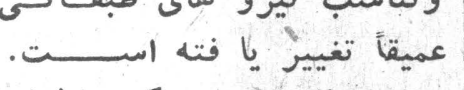

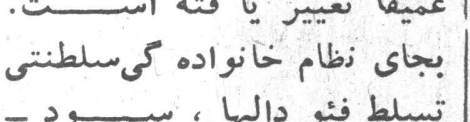

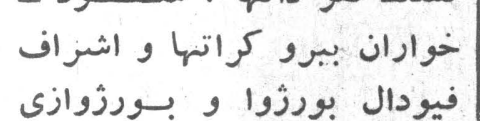

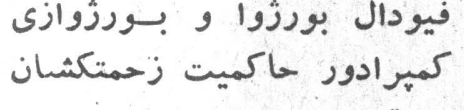

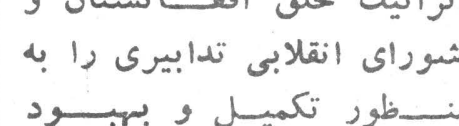
بر بر برار شده است

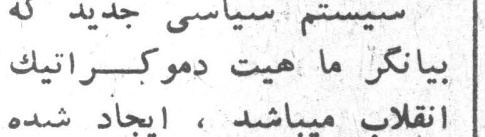

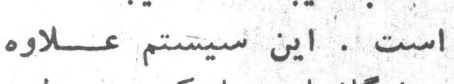

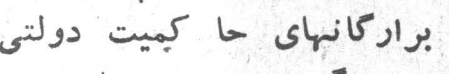

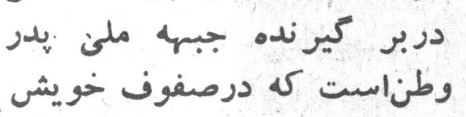

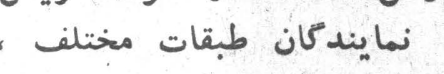

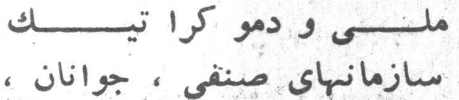

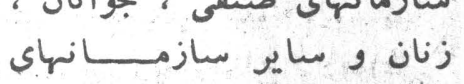

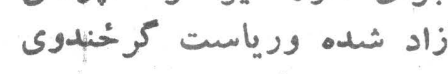

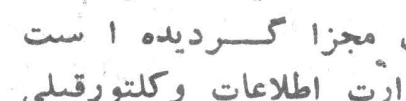

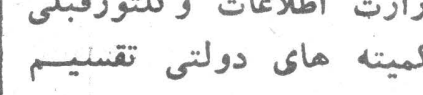

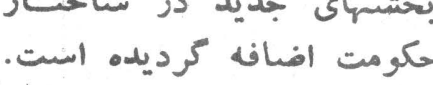

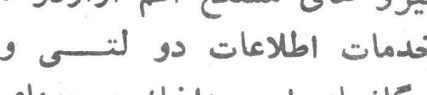

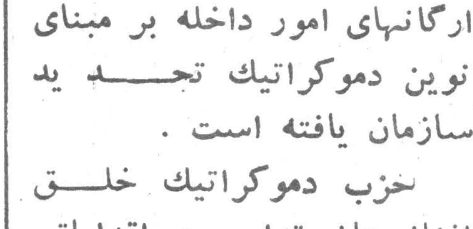
إنمان

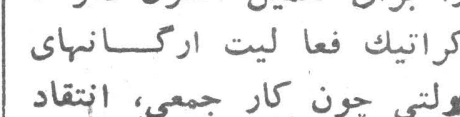

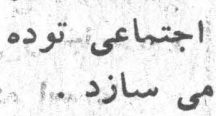

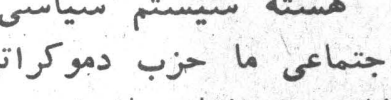

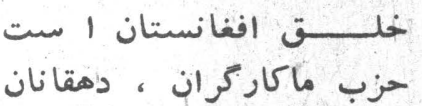

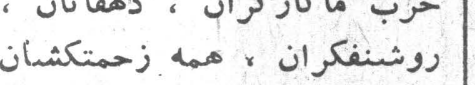

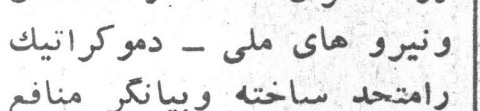
آنان وبيشآهنك سياخت وبيانكر منسفي

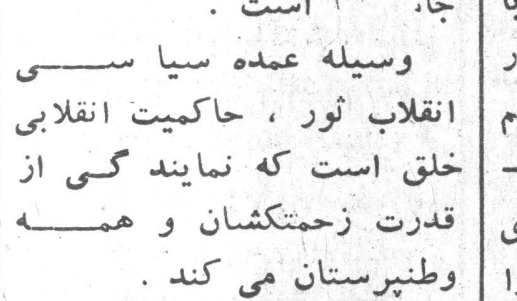

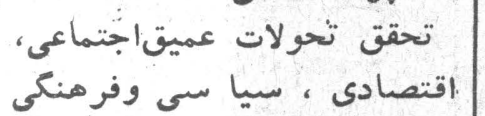

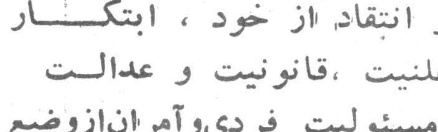
كاري

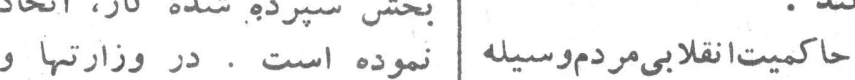

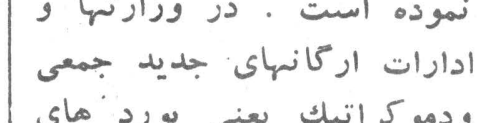

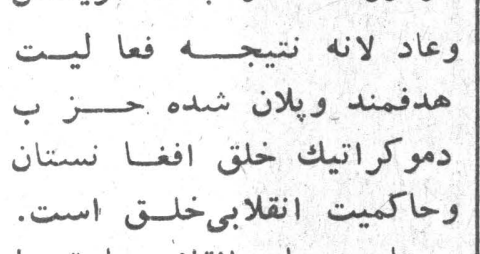

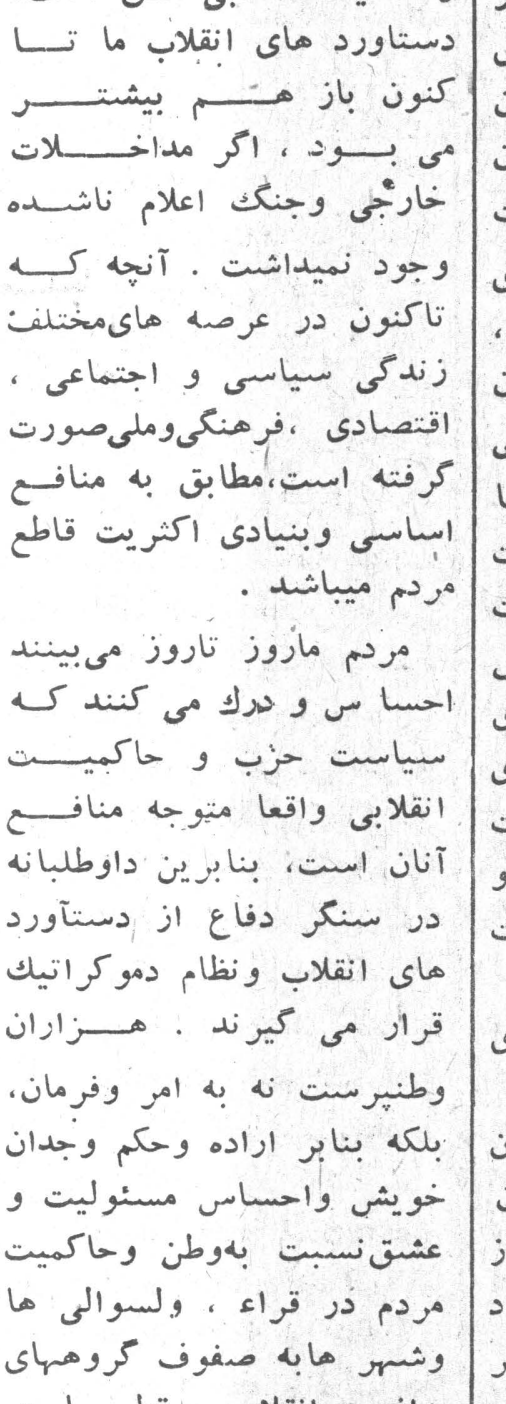

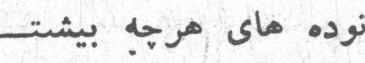

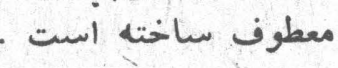

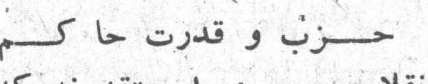

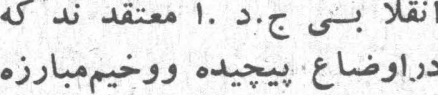

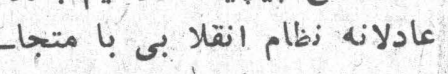
وزين اميريا ليستى و دشيمنان

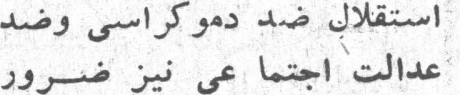

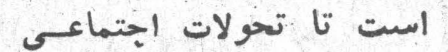

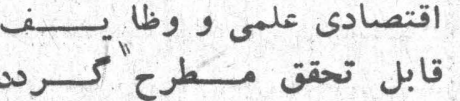

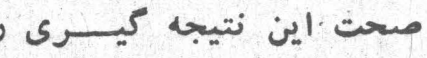

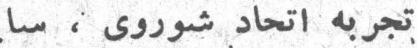

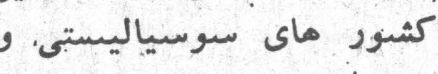

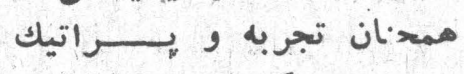

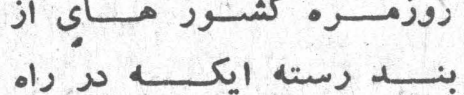

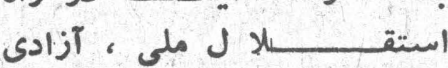

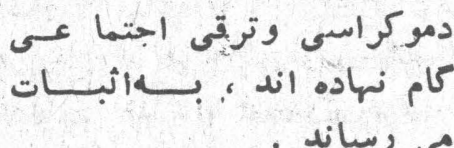
بروبلمهاددفاع ازحاكميت انقلابى مردم و اجرائ، تحولاتيك

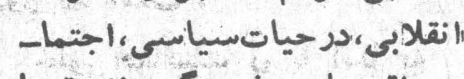

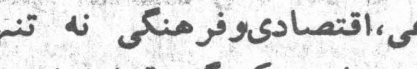
دربرابر يكديكر قرارنداشتها بكلك برعكس بامي ارتبـانس متقابل اركانيك دارند

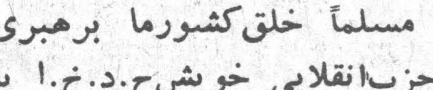

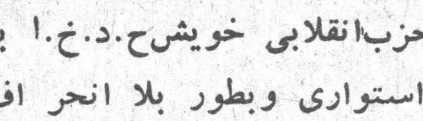

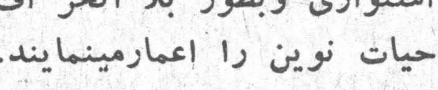

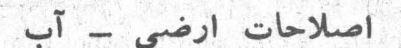

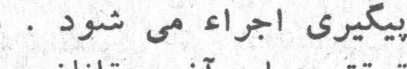

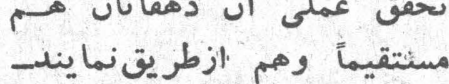
كان خويش در كميته ها

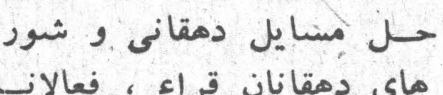

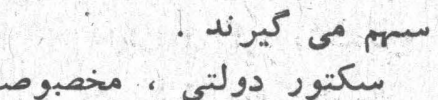

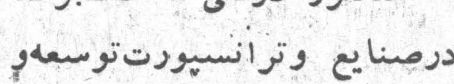

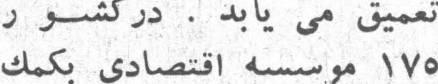
اتحاد شوروى اعمار كرديديد

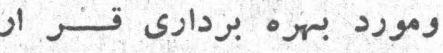
كرفته است . تعداد زيسادي

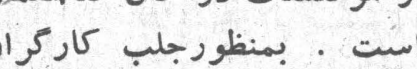

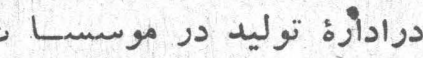

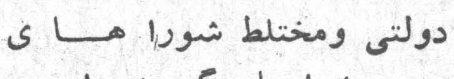
موسسه ايجاد كرديده است، كنة در تركيب آن نمايندكانسان كاركران وسازمانهائاجتماعى آنسان

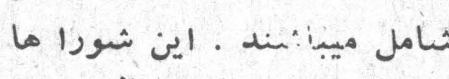
توليدى واقتصادى مو مو سيسات

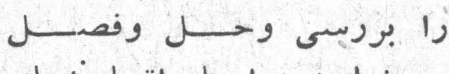
مى نمايند ، ايجاد اتحاديكهاي

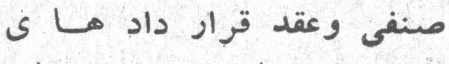
دستجمعى با ادارأ موسسسات

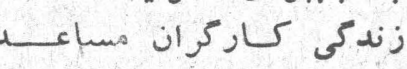

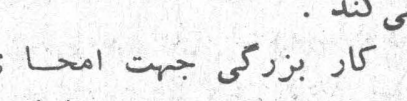
بيسوادى ، رثيد متسارف

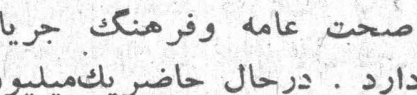
نفارد منجمله تعداد زاضر زيكاديليون

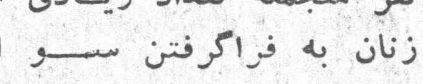

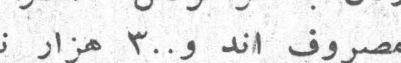




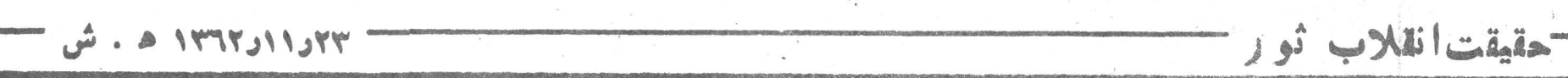

- صلصه جهادم -

\begin{tabular}{|c|c|c|c|c|c|c|}
\hline 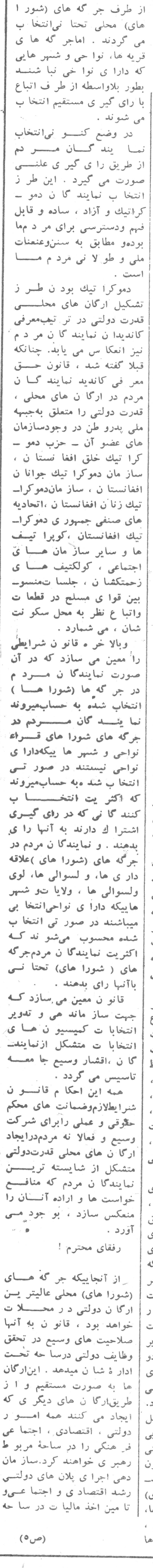 & 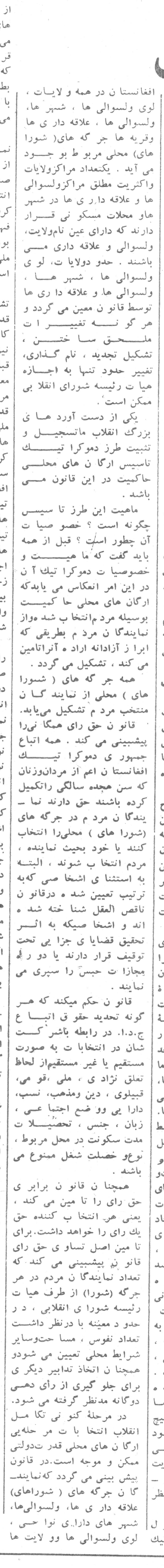 & 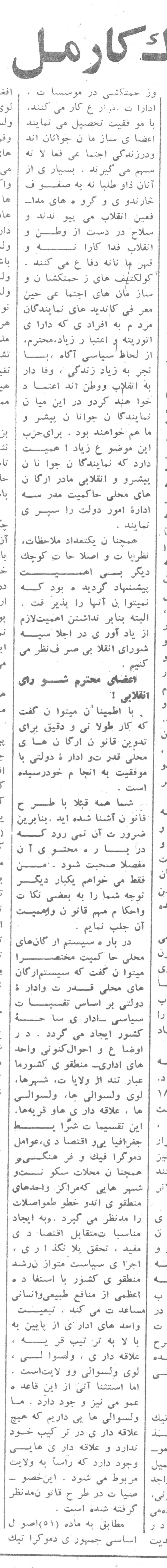 & 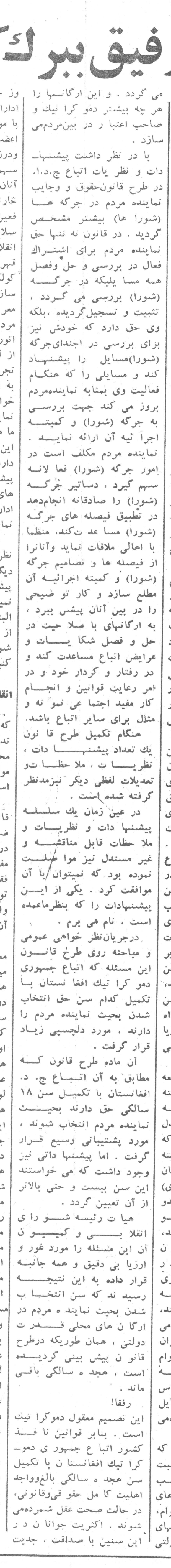 & 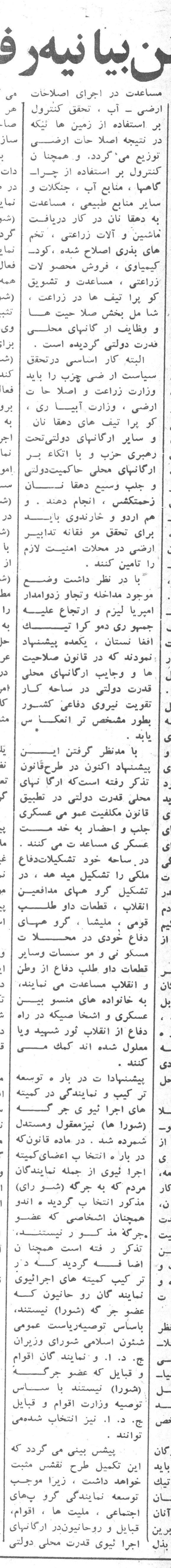 & 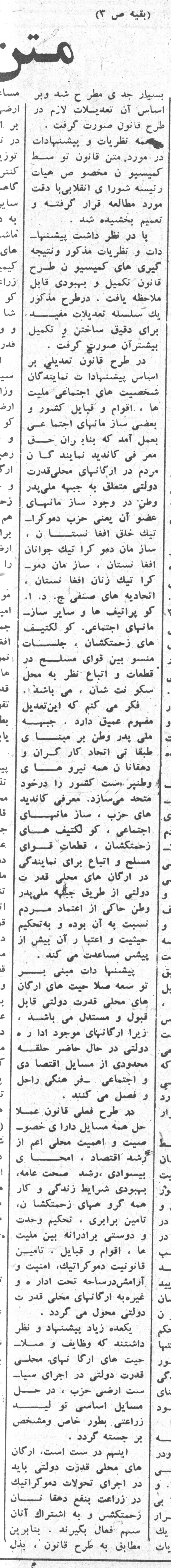 & 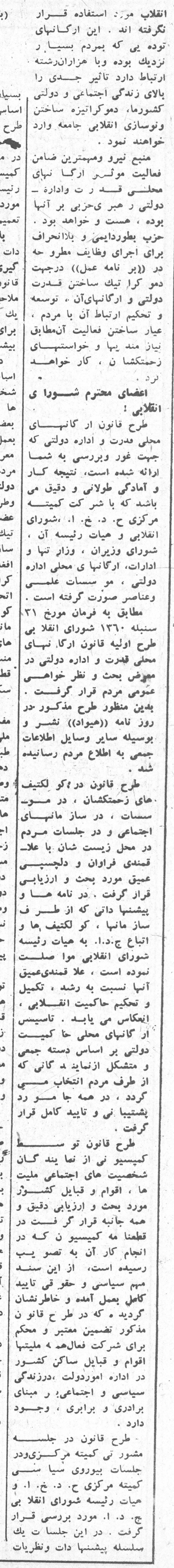 \\
\hline
\end{tabular}




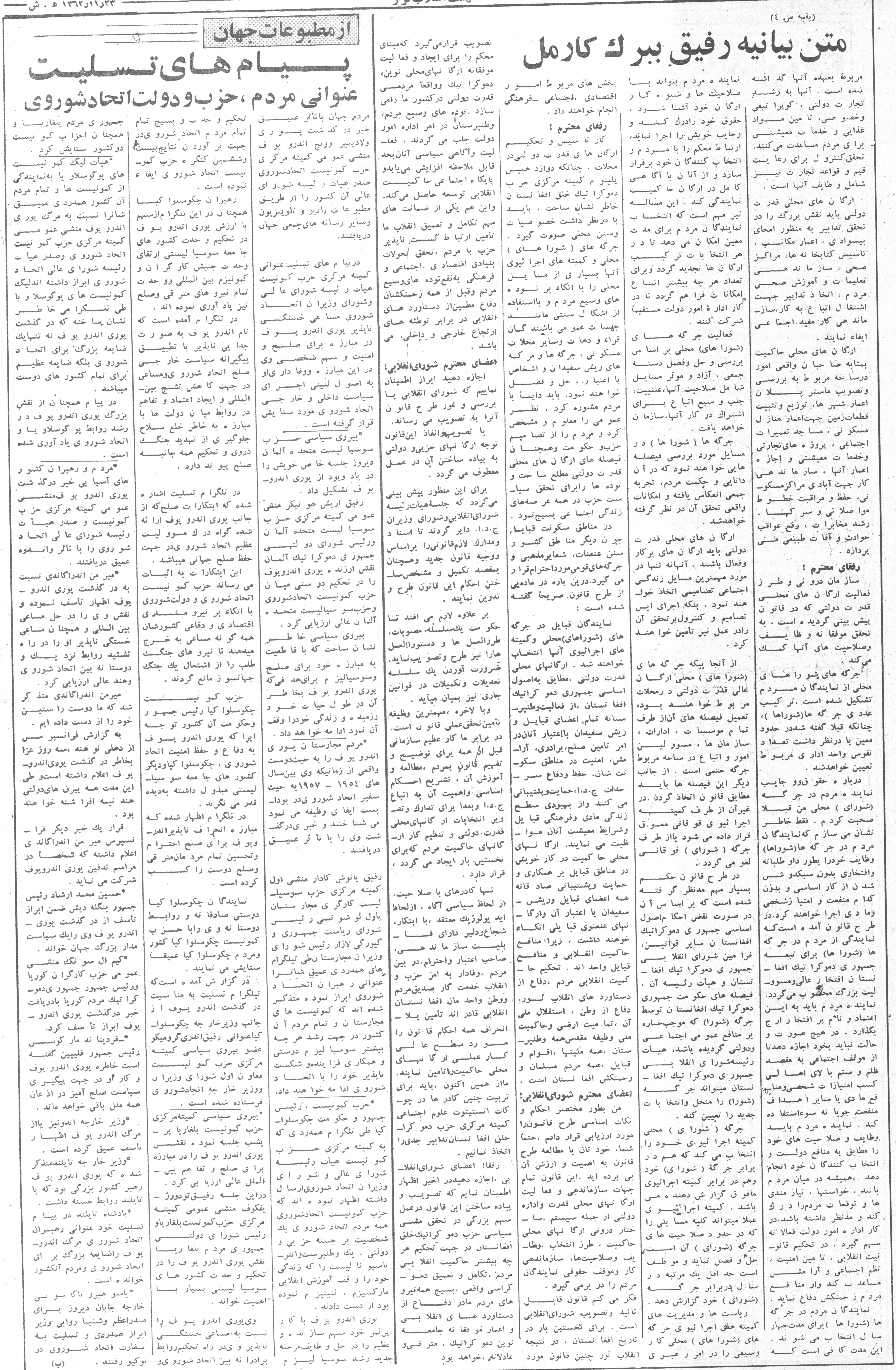




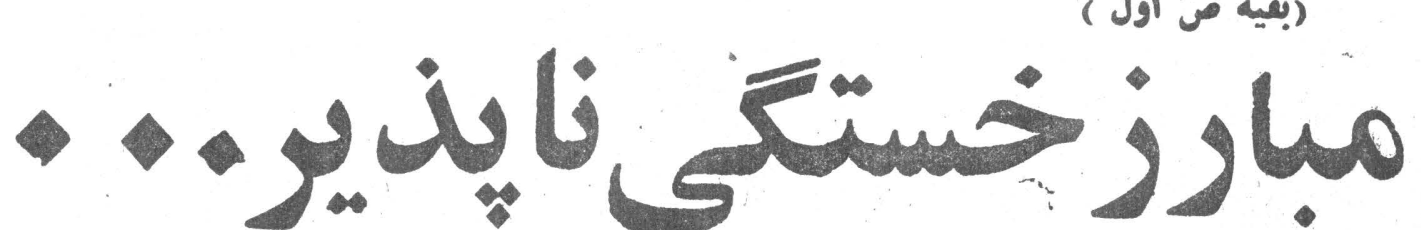

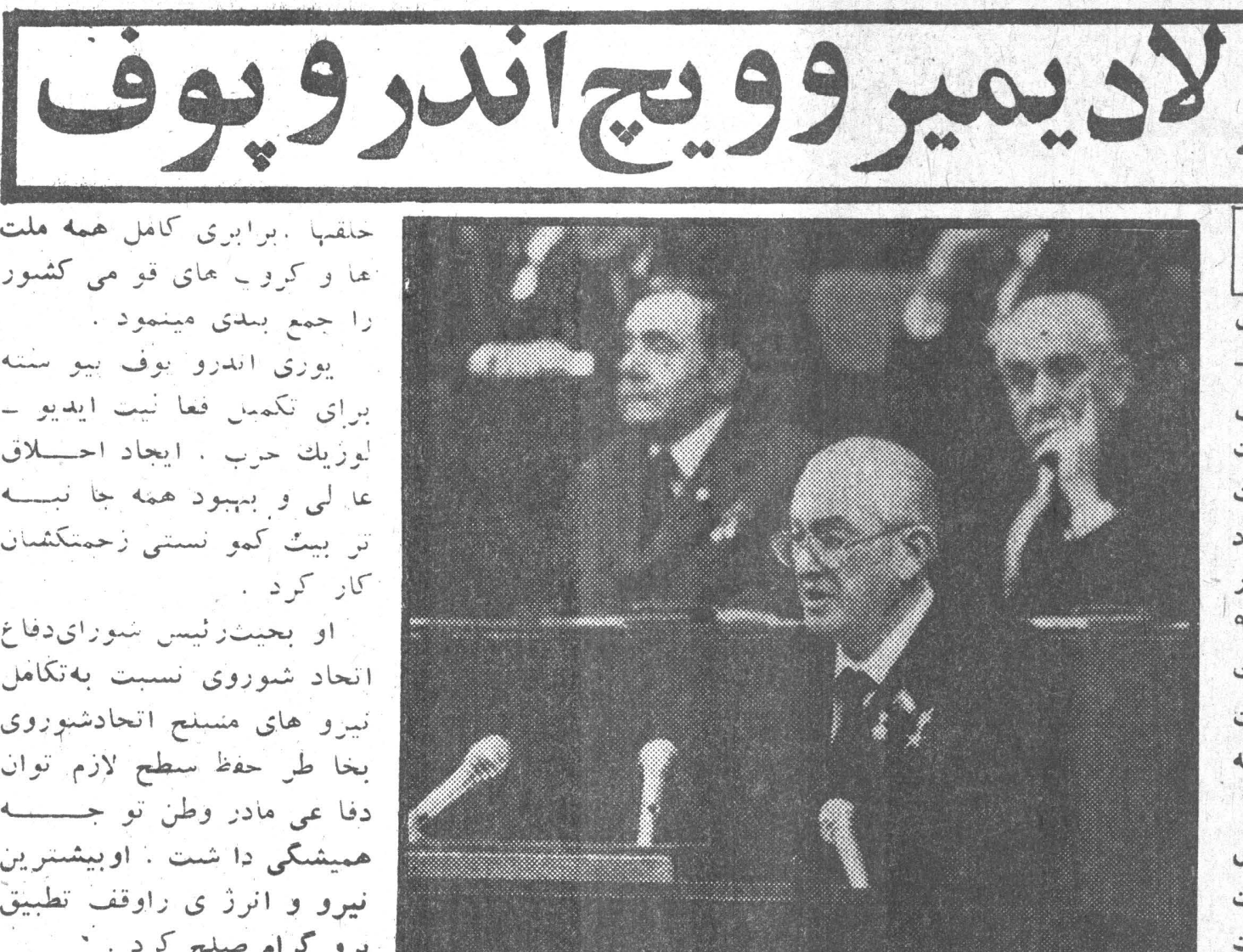

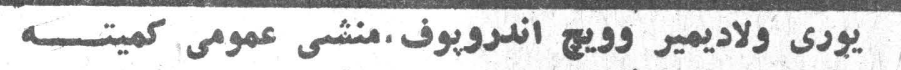

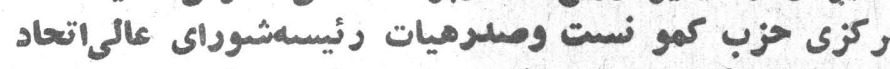

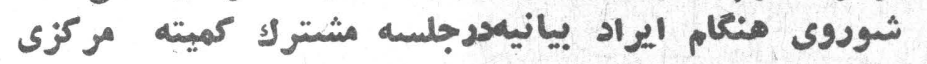

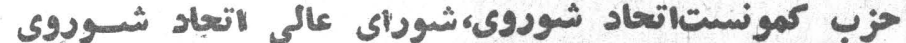

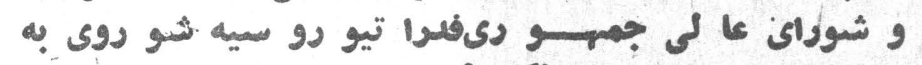

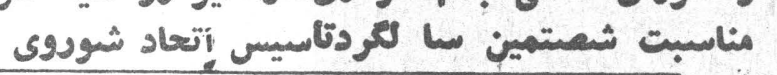

\section{ترن.}

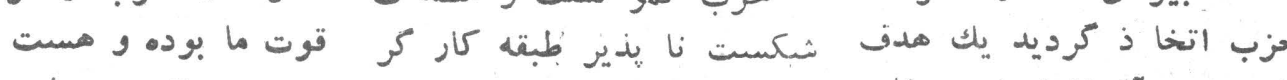

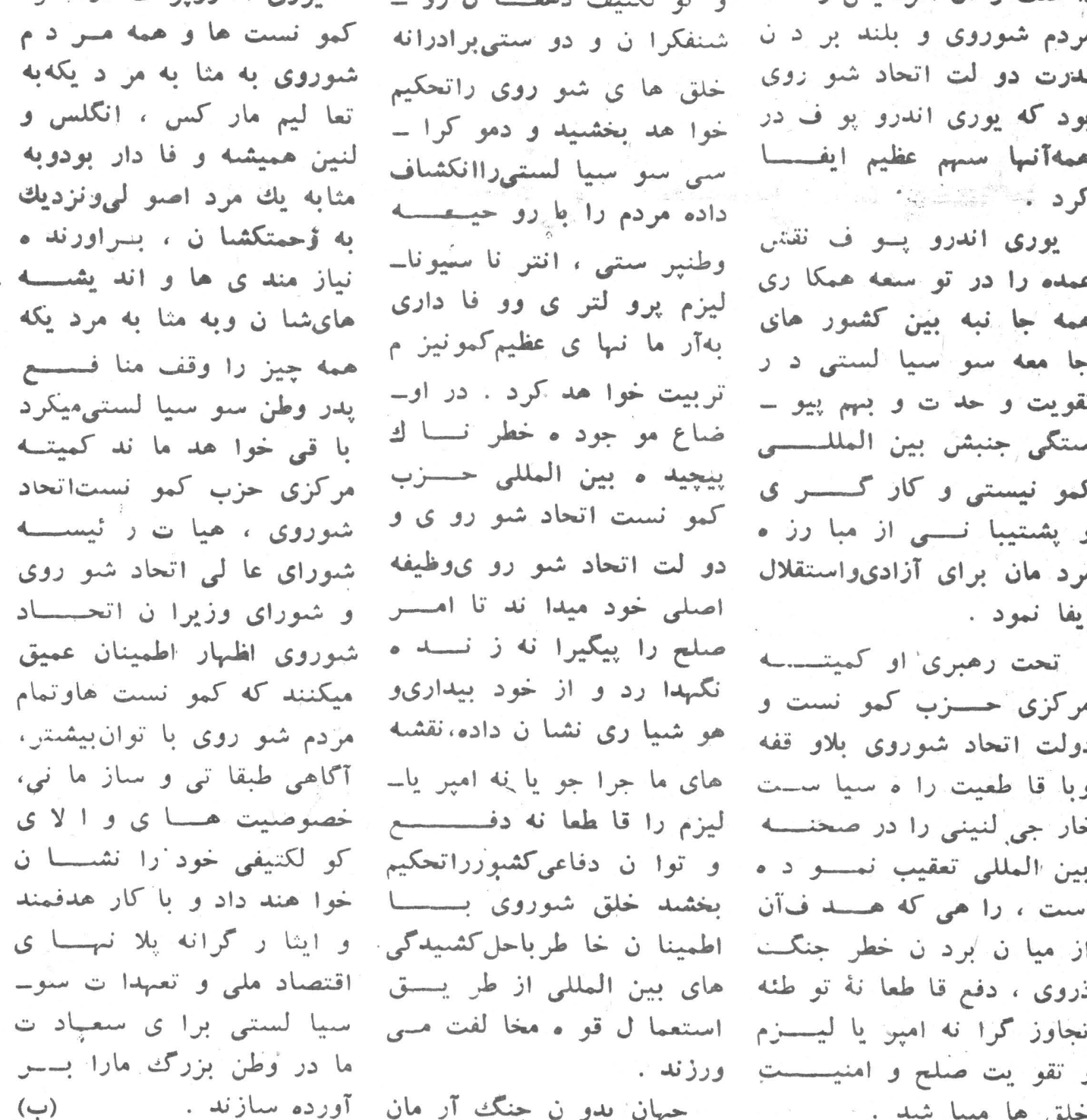

نو




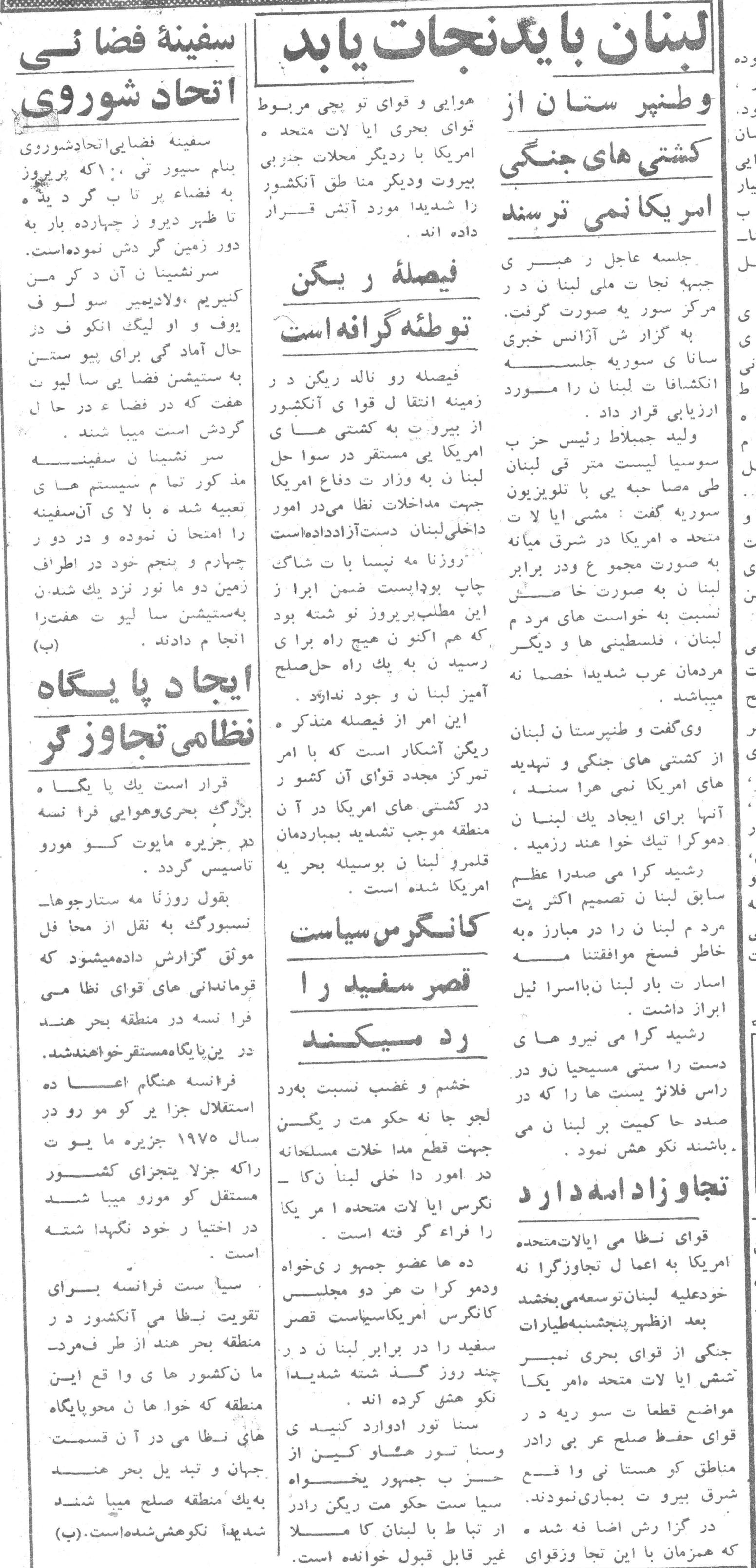

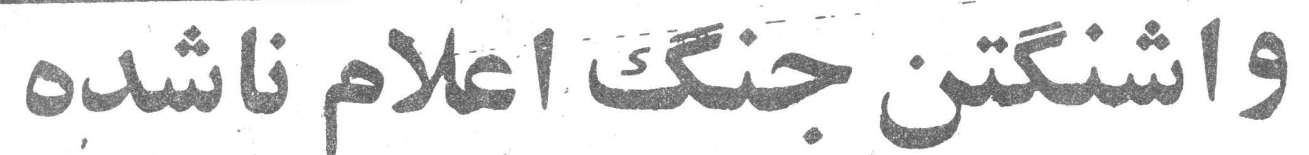

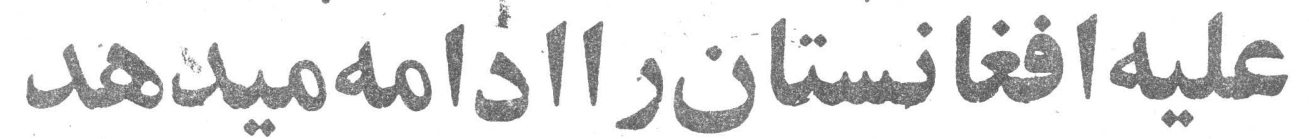

\begin{tabular}{|c|c|}
\hline 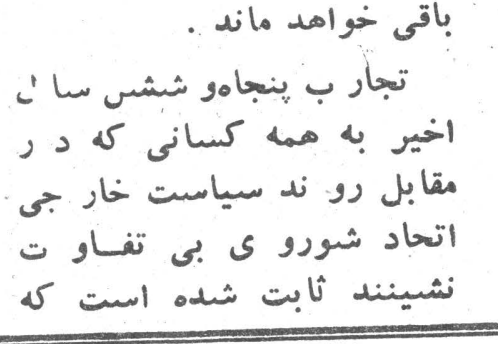 & 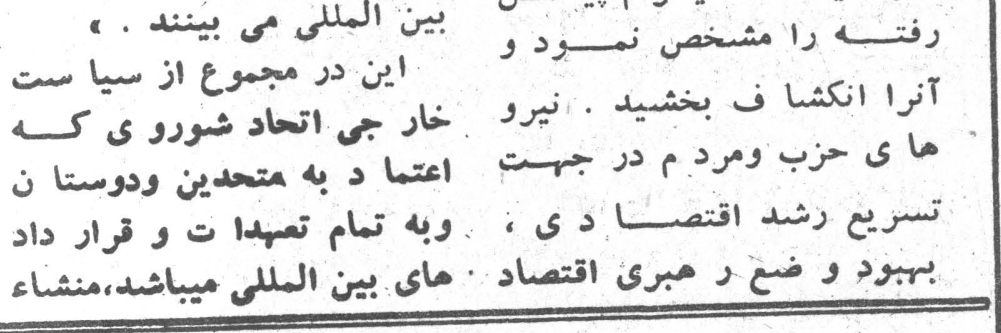 \\
\hline 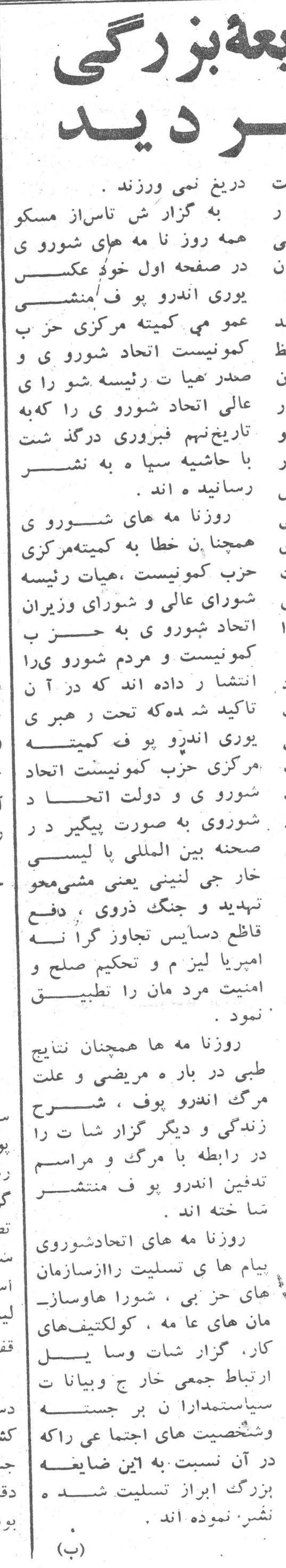 & 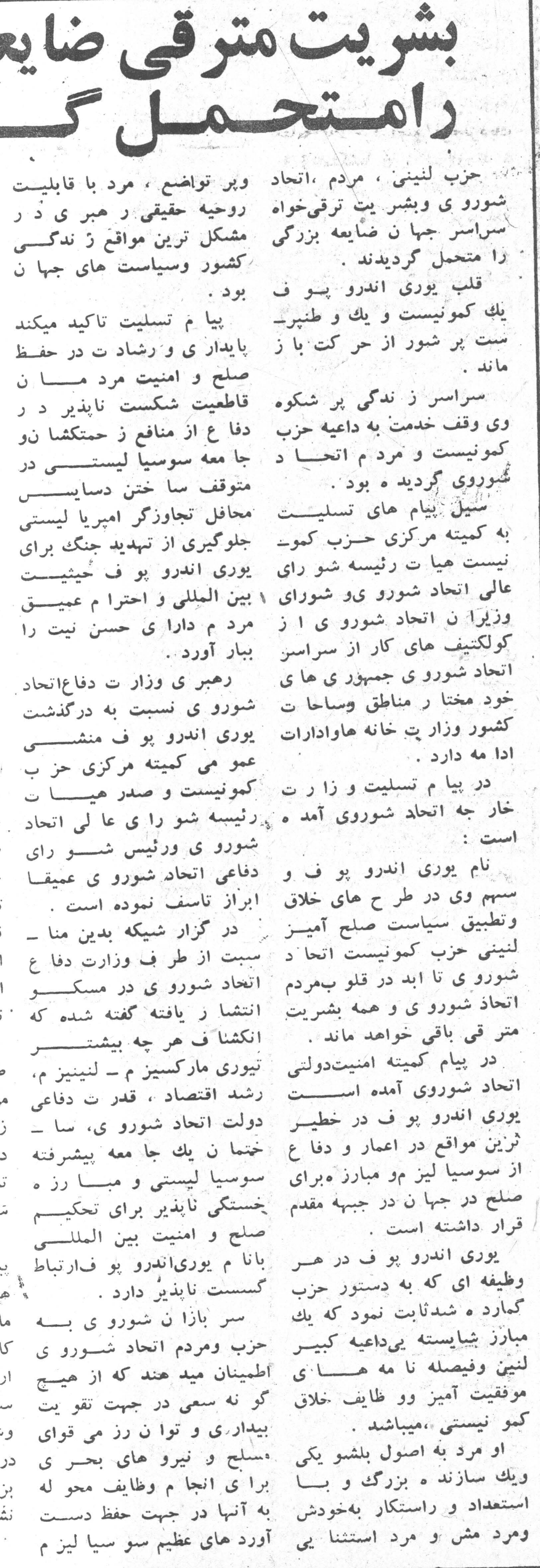 \\
\hline
\end{tabular}


S.

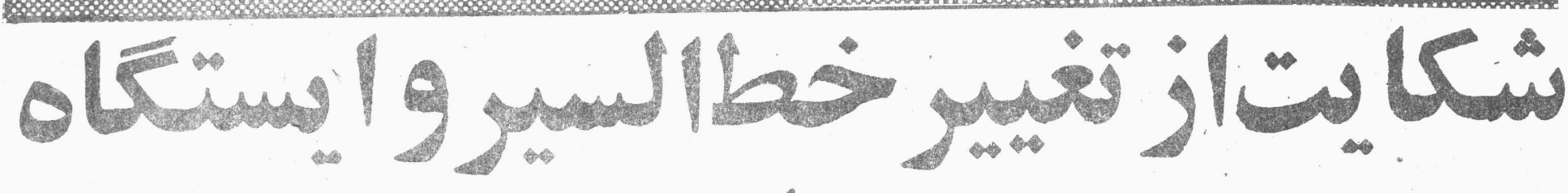

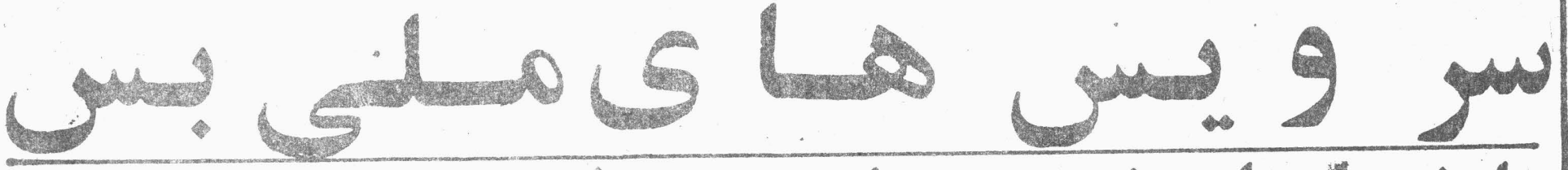

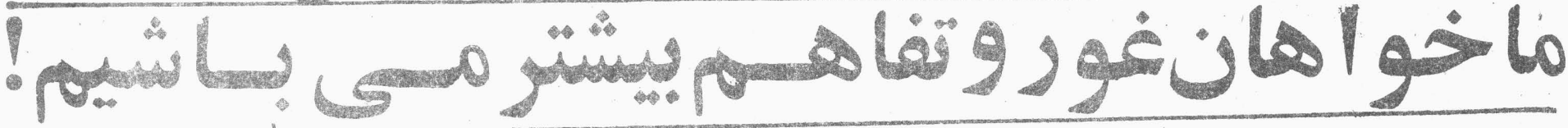

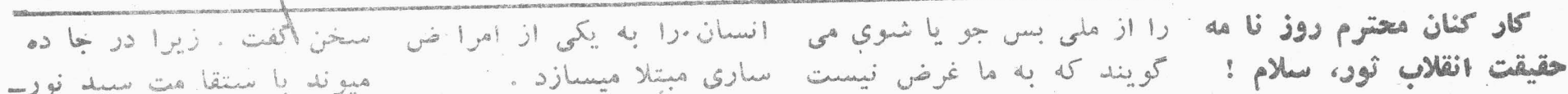

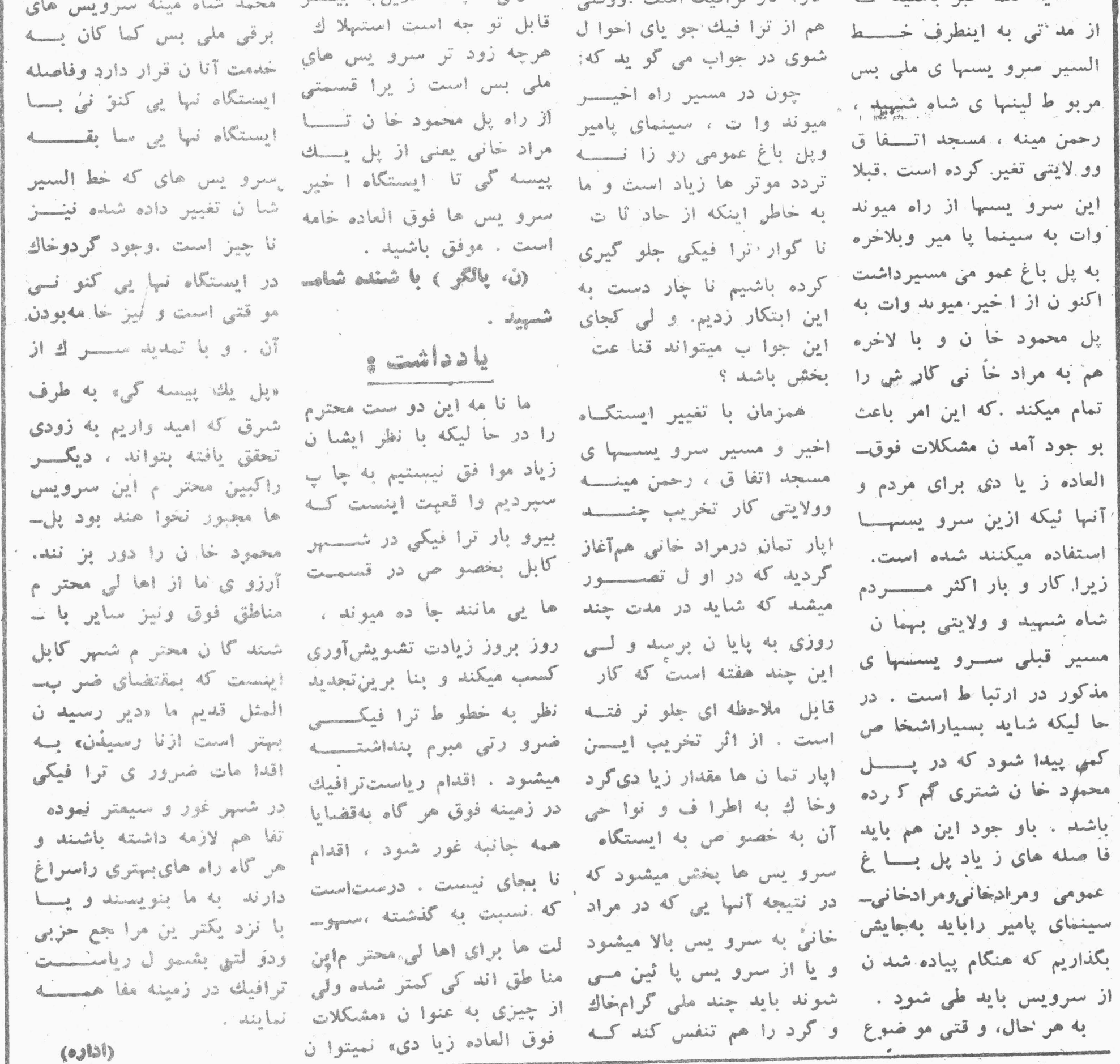

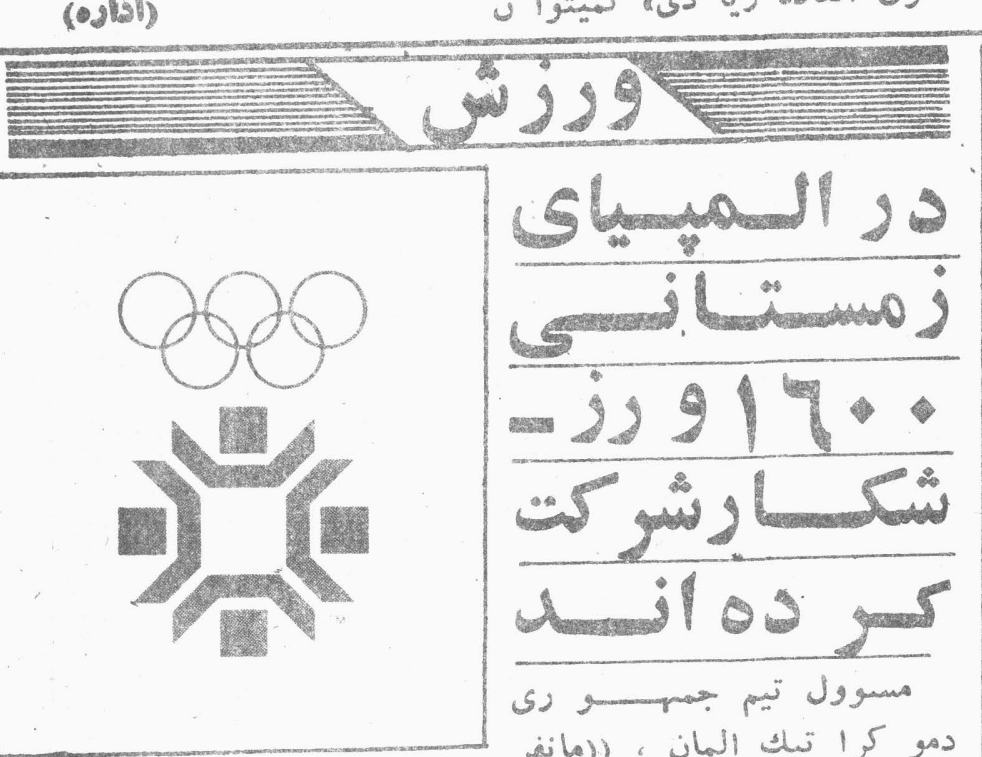

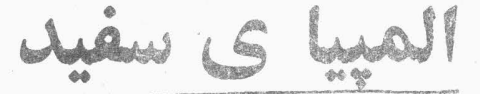

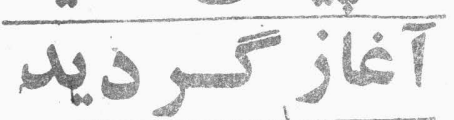

s,

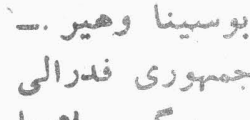

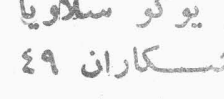

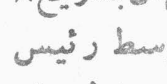

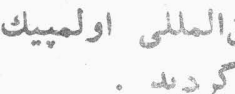

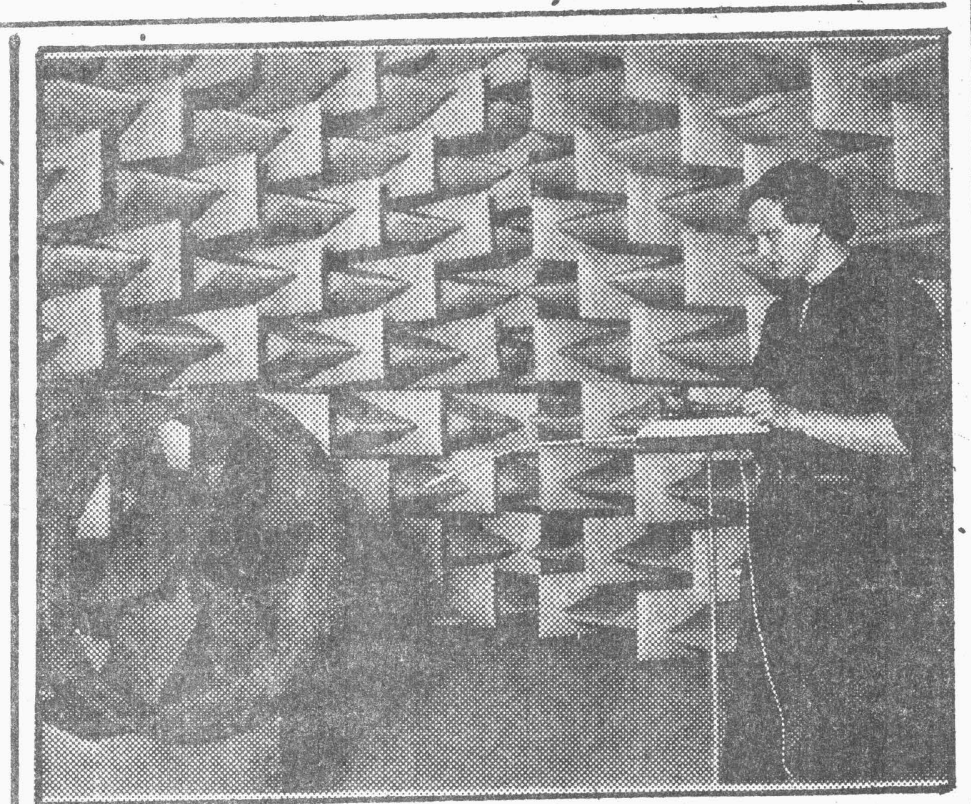

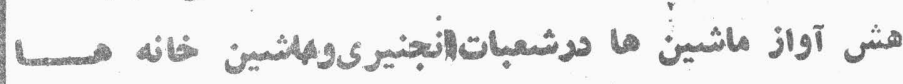

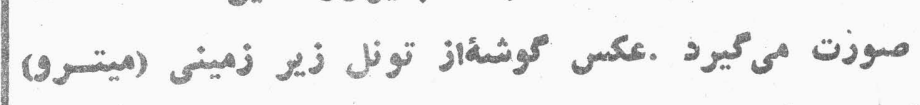

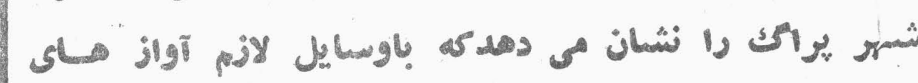

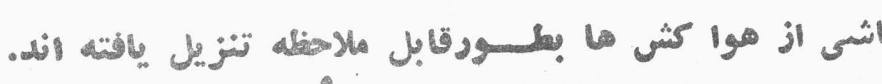

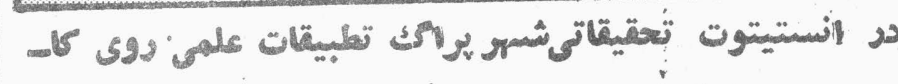

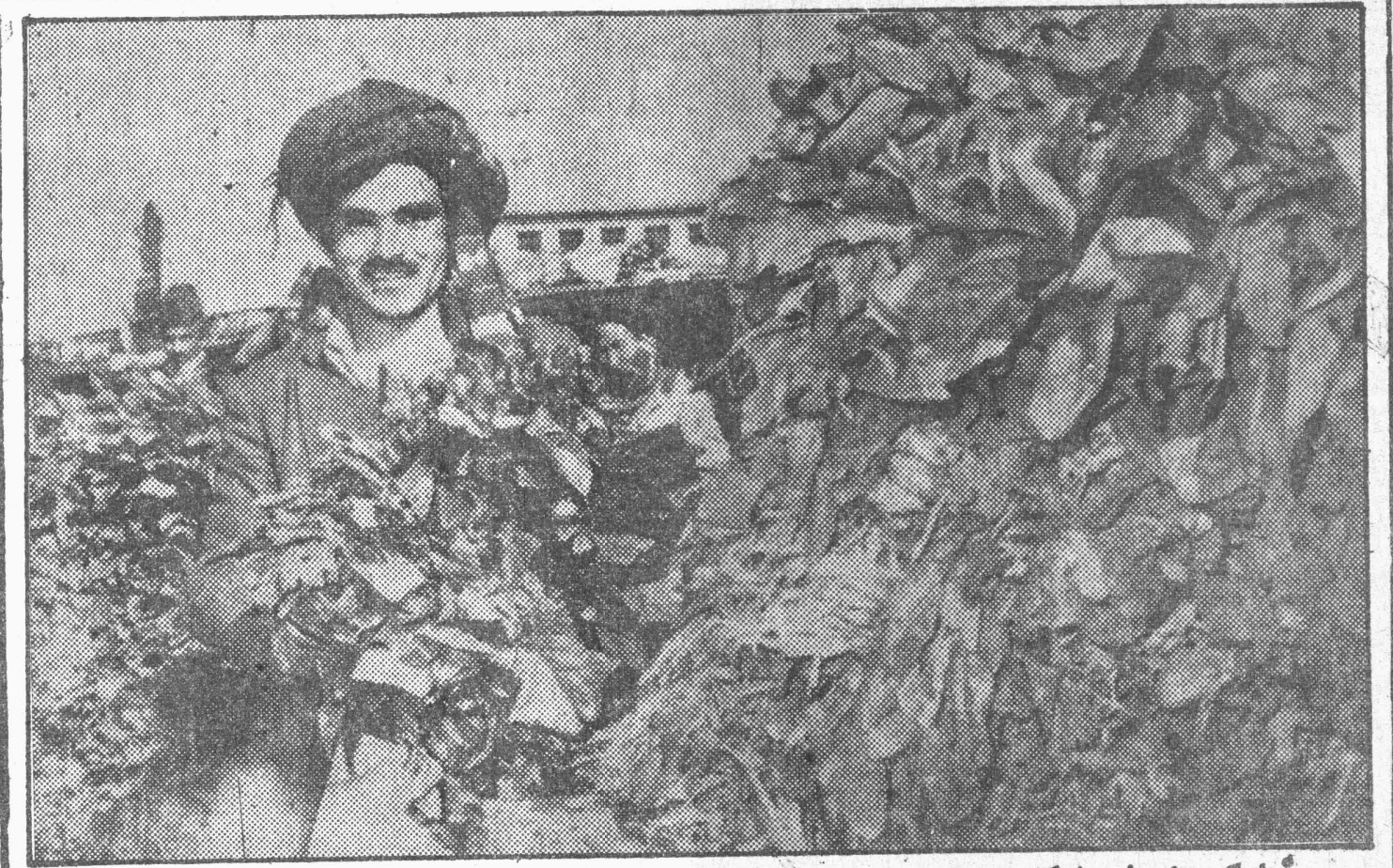

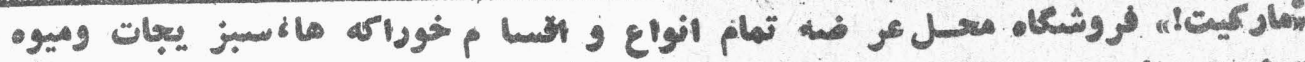

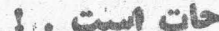

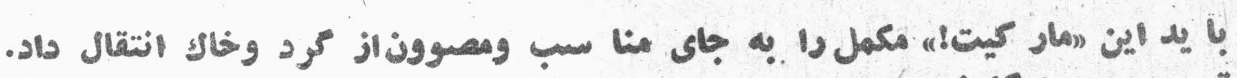

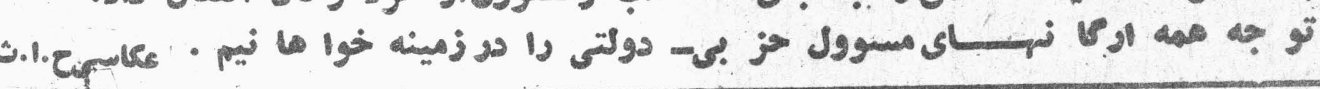

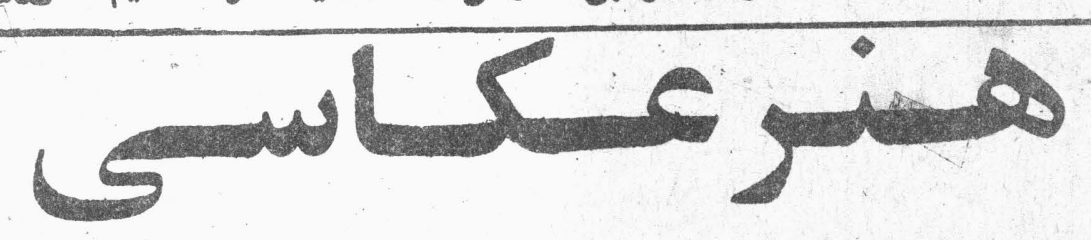

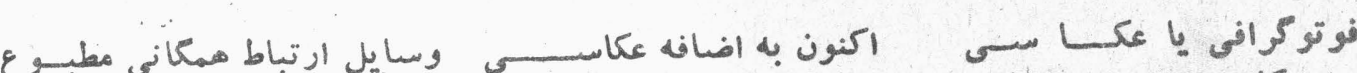

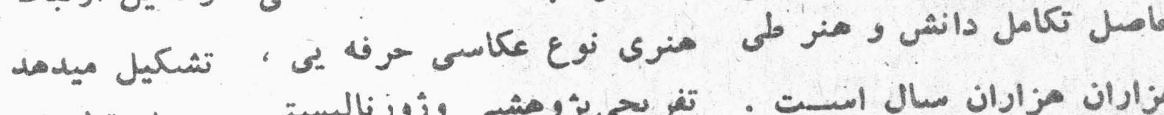

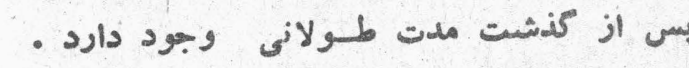

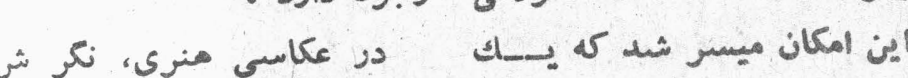

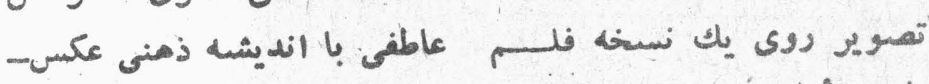

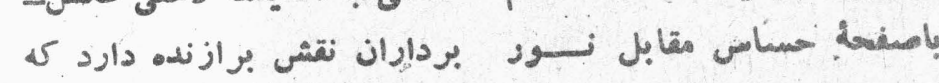

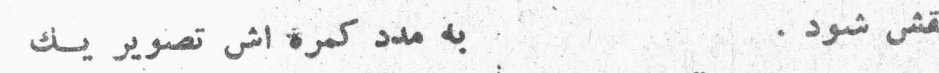

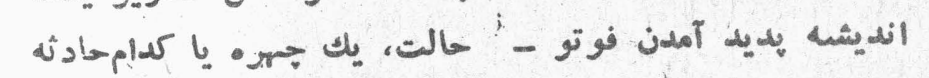

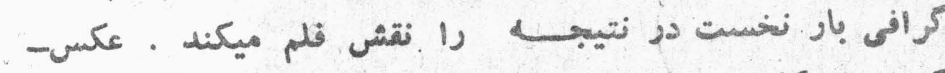

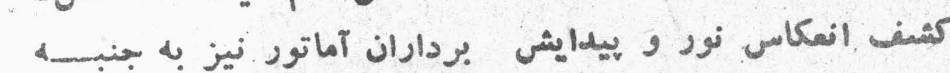

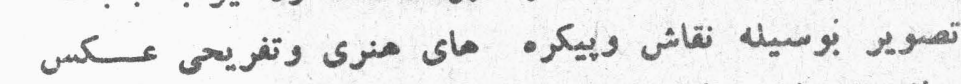

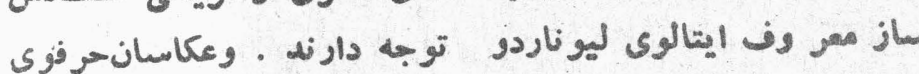

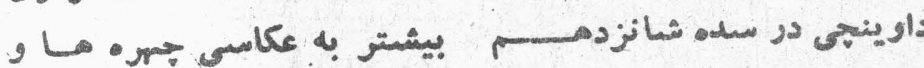

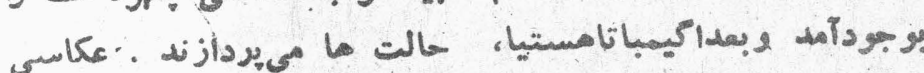

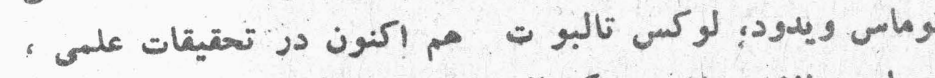

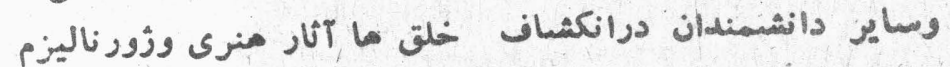

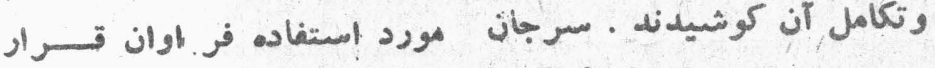

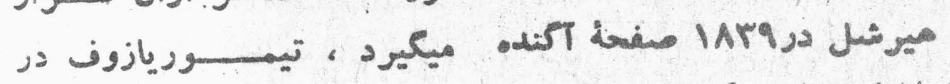

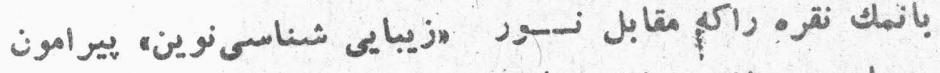

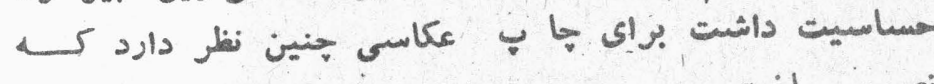

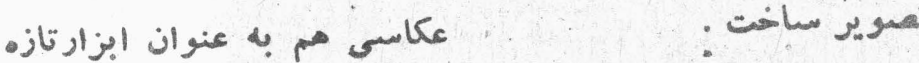

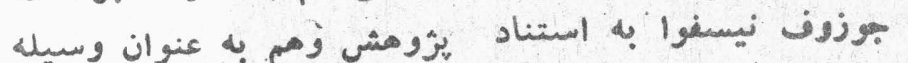

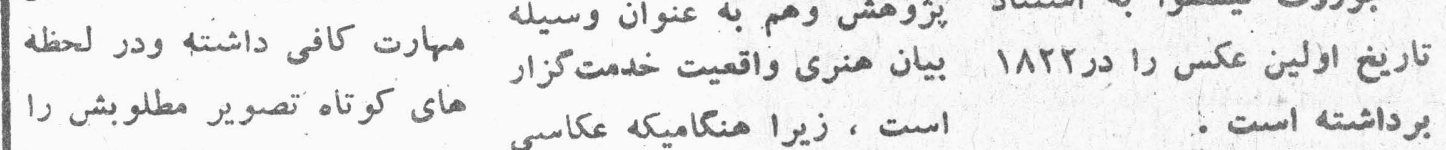

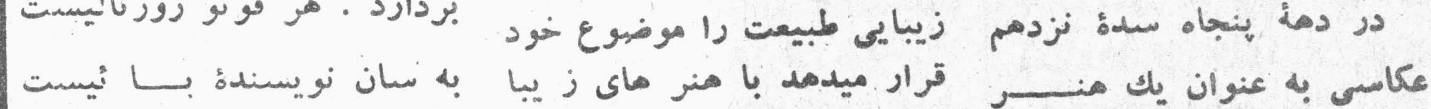

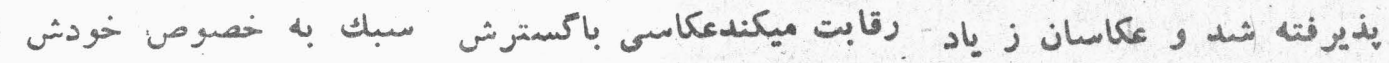

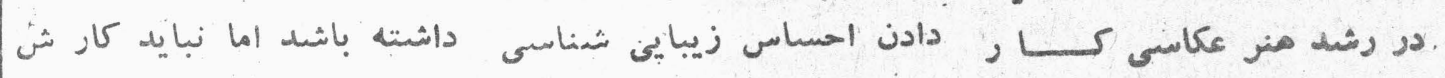

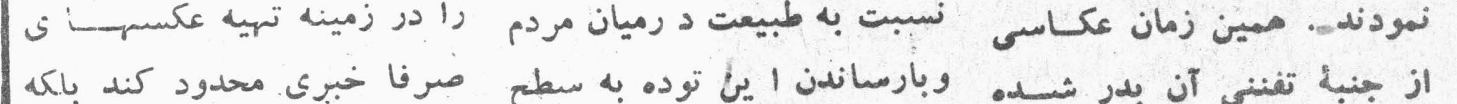

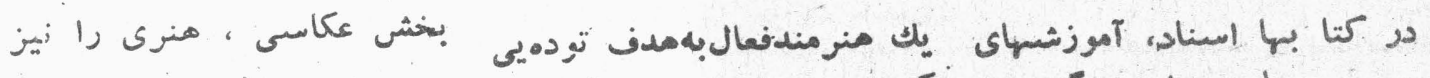

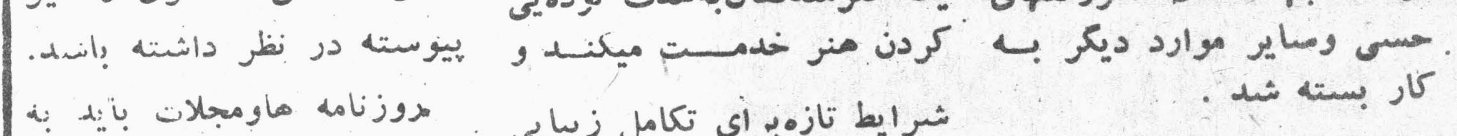

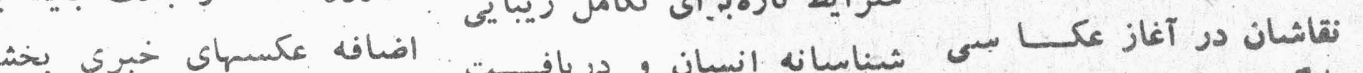

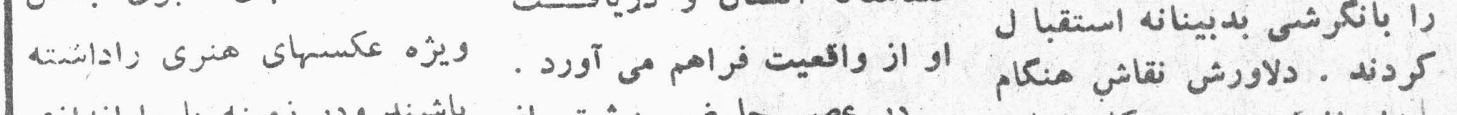

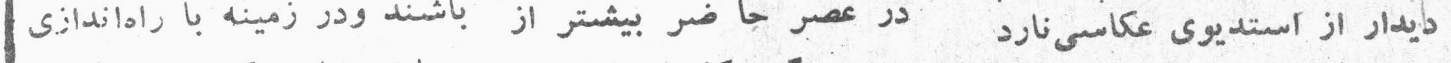

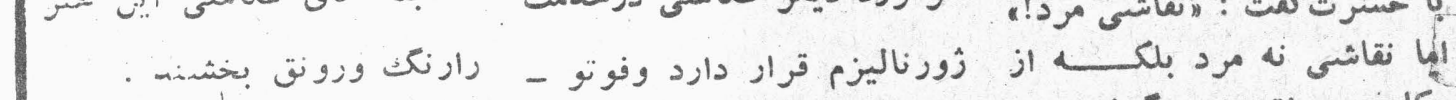
دانـ

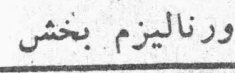

.

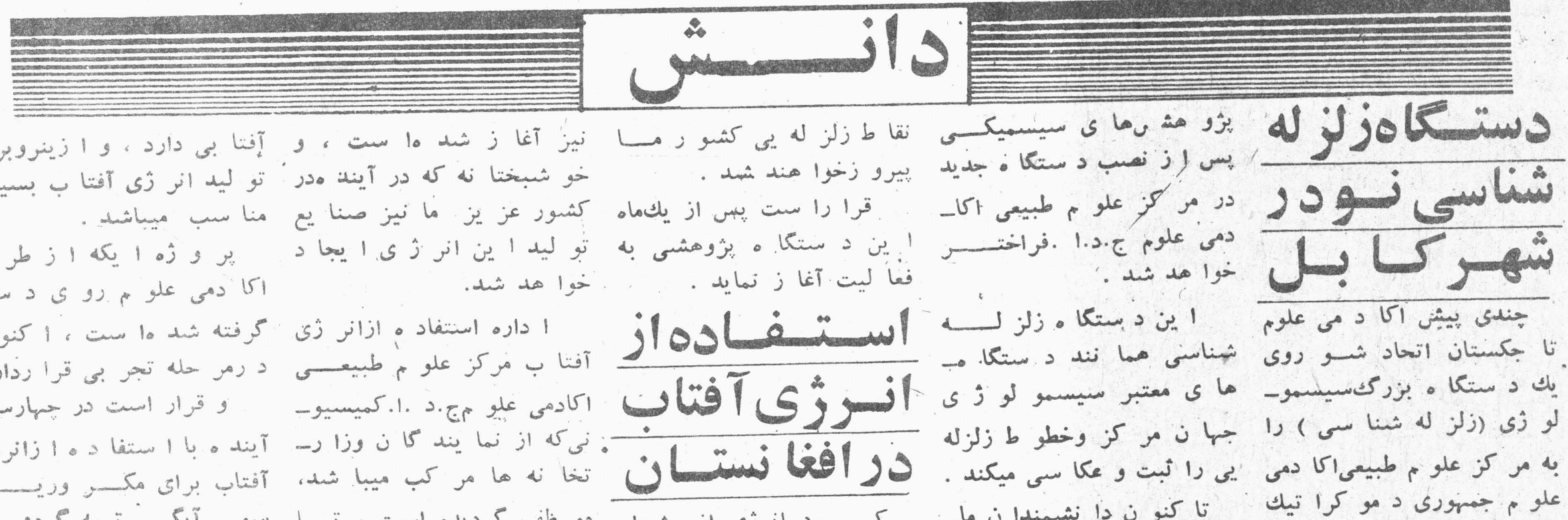

